\title{
Application of Multiple Geomatic Techniques for Coastline Retreat Analysis: The Case of Gerra Beach (Cantabrian Coast, Spain)
}

\author{
José Juan de Sanjosé Blasco ${ }^{1, * \mathbb{C}}$, Enrique Serrano-Cañadas ${ }^{2}{ }^{\circledR}$, Manuel Sánchez-Fernández ${ }^{1} \mathbb{D}$, \\ Manuel Gómez-Lende ${ }^{2}$ and Paula Redweik ${ }^{3}$ (D) \\ 1 Department of Graphic Expression, INTERRA Research Institute for Sustainable Territorial Development, \\ NEXUS Research Group Engineering, Territory and Heritage, University of Extremadura, \\ Avenida de la Universidad s/n, 10003 Cáceres, Spain; msf@unex.es \\ 2 Department of Geography, PANGEA Research Group Natural Heritage and Applied Geography, \\ University of Valladolid, Plaza del Campus s/n, 47011 Valladolid, Spain; serranoe@fyl.uva.es (E.S.-C.); \\ manuelglende@hotmail.com (M.G.-L.) \\ 3 Department of Engenharia Geográfica, Geofísica e Energia and Instituto Dom Luiz, Faculdade de Ciências, \\ University of Lisbon, 1649-004 Lisbon, Portugal; pmredweik@fc.ul.pt \\ * Correspondence: jjblasco@unex.es
}

Received: 12 October 2020; Accepted: 7 November 2020; Published: 9 November 2020

\begin{abstract}
The beaches of the Cantabrian coast (northern Spain) are exposed to strong winter storms that cause the coastline to recede. In this article, the coastal retreat of the Gerra beach (Cantabria) is analyzed through a diachronic study using the following different geomatic techniques: orthophotography of the year 1956; photogrammetric flights from 2001, 2005, 2010, 2014, 2017; Light Detection and Ranging (LiDAR) survey from August 2012; Unmanned Aerial Vehicle (UAV) survey from November 2018; and terrestrial laser scanner (TLS) through two dates per year (spring and fall) from April 2012 to April 2020. With the 17 observations of TLS, differences in volume of the beach and the sea cliff are determined during the winter (November-April) and summer (May-October) periods, searching their relationship with the storms in this eight-year period (2012-2020). From the results of this investigation it can be concluded that the retreat of the base of the cliff is insignificant, but this is not the case for the top of the cliff and for the existing beaches in the Cantabrian Sea where the retreat is evident. The retreat of the cliff top line in Gerra beach, between 1956 and 2020 has shown values greater than $40 \mathrm{~m}$. The retreat in other beaches of the Cantabrian Sea, in the same period, has been more than $200 \mathrm{~m}$. With our measurements, investigations carried out on the retreat of the cliffs on the Atlantic coast have been reinforced, where the diversity of the cliff lithology and the aggressive action of the sea (storms) have been responsible for the active erosion on the face cliff. In addition, this research applied geomatic techniques that have appeared commercially during the period (1956-2020), such as aerial photogrammetry, TLS, LiDAR, and UAV and analyzed the results to determine the precision that could be obtained with each method for its application to similar geomorphological structures.
\end{abstract}

Keywords: coastal geomorphology; shoreline change; coastal process; monitoring; geomatic techniques

\section{Introduction}

Coastal changes, at a geological scale, are very slow and the morphology of beaches and cliffs retain features of earlier sea levels, but there are changes, at a human scale, that can be easily detected along the coastline. Two main findings from the study of sea cliff evolution highlight the temporal change in cliff top line recession mode, and the effect of beach sediment at the cliff toe on cliff erosion. [1,2] pointed out that our ability to quantify sea cliff retreat rates and their variability through time was the first 
step to understanding the sea cliff erosion processes and also the responses to environmental and climate changes. Information about the factors responsible for triggering gravitational landslides (rockfalls, slides, and debris falls) has been provided by high resolution and high frequency monitoring.

Measures on sea cliff recession show distinct behaviors at different geographical locations and geological structures, and the spatial variations of the cliff retreat rates have been explained by changes in the geological structure, cliff collapses, or anthropogenic obstacles [3,4]. Twelve years (1998-2010) of coastal cliff erosion and retreat, measured by airborne light detection and ranging (LiDAR), of the California coast have shown that less than $50 \%$ of the coast was active and the mean recent retreat rates were $52-83 \%$ lower than mean historical retreat rates. Locations with elevated historical retreat had low levels of recent retreat and locations with elevated recent retreat were preceded by low rates of historical retreat [5]. In addition, in the Mediterranean, recent short-term (i.e., annual to decadal) cliff top retreat rates exceeded longer term rates of "background" (i.e., centennial to millennial) retreat by one to two orders of magnitude [1], however, the authors pointed out that an inherent sampling bias in rate estimates inferred from shorter observation intervals could also have explained such a pattern. In the Atlantic coast, the retreat rates obtained from historical maps, aerial photographs, recent TLS and photogrammetry monitoring were -10 to $-50 \mathrm{~cm} / \mathrm{yr}$ [3]. The behavior of cliffs characterized by landslides on beaches are related to several factors, depending on climate, structural geology, lithology, and sea exposure. On European Atlantic coasts, they are also under the dominant influence of precipitation and the evolution of the groundwater level [3].

Coastline and sea cliff retreats have been checked for the Cantabrian Coast (northern Spain) over the past 40 years [6-12], where major sand changes and cliff failure events have occurred at several points along the beaches and sea cliff systems. Since the mid-twentieth century, storms have been of major importance and are an important public concern, reaching inhabited areas and causing damage to private property on sand systems and cliff tops. Strong wind and storm wave events imply bigger and faster spatial and temporal changes in the cliffs. Retreat and changes occur due to sudden impulses related to storms where interactions between rock strength, structure, lithology and wave action, rainfall, temperature variations, and runoff generate cliff processes such as rock falls, topples, and slides, as well as sand movements [12-15]. These facts are of significant relevance to public authorities because the public safety of residential areas along the cliffs is threatened. Therefore, the processes and causes of sea cliff instability and quick changes must be understood at a detailed scale in order to provide authorities with data-driven models of cliff erosion in time and space [16-18]. The concern about shoreline response to climate change has also increased in the social and scientific environment [19-21].

The applied techniques for costal studies are as diverse as the objectives of the studies. Synthetic aperture radar (SAR) images have been applied for an automatic extraction of the shoreline [22]. For the determination of wave run-up on a beach, video footage from two cameras has been processed [23]. The relevance of the width of the observation time window for monitoring coastal region dynamics has led researchers to resort to very different data originating from older records and newer acquisition techniques. Traditionally, the most common methodologies to evaluate cliff changes and retreat have been the analysis of historical aerial photographs, topographic maps, and survey plans covering several decades. Retreat rates have usually been quantified on the cliff top, yielding incomplete information because the data accuracy of available aerial images has been metric or decimetric and the point of view has only been vertical looking downwards [16,17]. Terrestrial laser scanner (TLS) has been applied in recent years for the same purpose, due to the rapid progress regarding maximum scanning range, spatial resolution, and accuracy and the fact that it allows a higher frequency of geomatic surveys [24]. This technique can monitor the evolution cliffs and beaches, and it can be used to investigate processes on the cliff top, cliff faces, and the cliff toe, as well as beaches located at the base of the cliffs $[12,16,17,25-33]$.

The aim of the present work is to detect changes in the cliff top, face, and base, and to map the deformation of the cliff by using four different geomatic techniques (aerial photogrammetry, light detection and ranging (LiDAR), unmanned aerial vehicle (UAV), and terrestrial laser scanning 
(TLS). Available data on the 20th century Gerra beach consist of photogrammetric flights which had low precision (high flight height). Fortunately, the same did not happen with the photogrammetric flights during the 21st century, which were used for the stereophotogrammetric plotting. Geomatic techniques that have been developed since the beginning of the 21st century, such as LiDAR, TLS, and UAV, have also been used. Specifically, TLS has been used, for eight years, leading to a continuous series of 17 surveys for estimating erosive changes at a detailed scale and for understanding the processes involved in the retreat of the coastline. The TLS surveys took place before and after the storm period (December-March) and in this way the behavior of the beach could be analyzed against the occurrence of storms. The data collected for this project were used for different types of analyses, some of them in a time span of 64 years, which was remarkably long as compared with most projects described in literature. The longer the time span, the sounder the conclusions about cliff erosion.

This research is part of a long-term monitoring program to better understand and quantify geomorphic behavior and local retreat rates of the Cantabrian coast. The ultimate goal is to provide useful information to the local planning authorities, as the cliff tops close to the Gerra beach suffer similar slope processes and cliff erosion. Until now, there has been no data on cliffs' instability in this study area or on the Cantabrian cliffs.

\section{The Study Area}

The Cantabria coast is located in northern Spain, facing the Cantabrian Sea. It is a mesotidal environment with a tidal range of $4 \mathrm{~m}$. Cantabria has a maritime west coast climate with average winter temperatures around $14-15^{\circ} \mathrm{C}$. Rainfall is distributed over the year (ca. 1000-1200 mm/year). The main coast landforms are steep cliffs, which occupy $77 \%$ of the Cantabria coast, from $20 \mathrm{~m}$ to $70 \mathrm{~m}$ height on average, alternated by embayed beaches and small estuaries, both with aeolian dune fields. The main beaches are located out of estuaries, as the San Vicente-Merón beaches, where the Gerra beach is located (Figure 1) [34]. The cliff top was shaped by the sea processes, as marine deposits and ancient abrasion platforms, locally named "rasas", raised between 4 and $285 \mathrm{~m}$ height. Together with the wide platforms, some erosional features on cliffs and slopes are related to marine erosion and sedimentation [35-38].

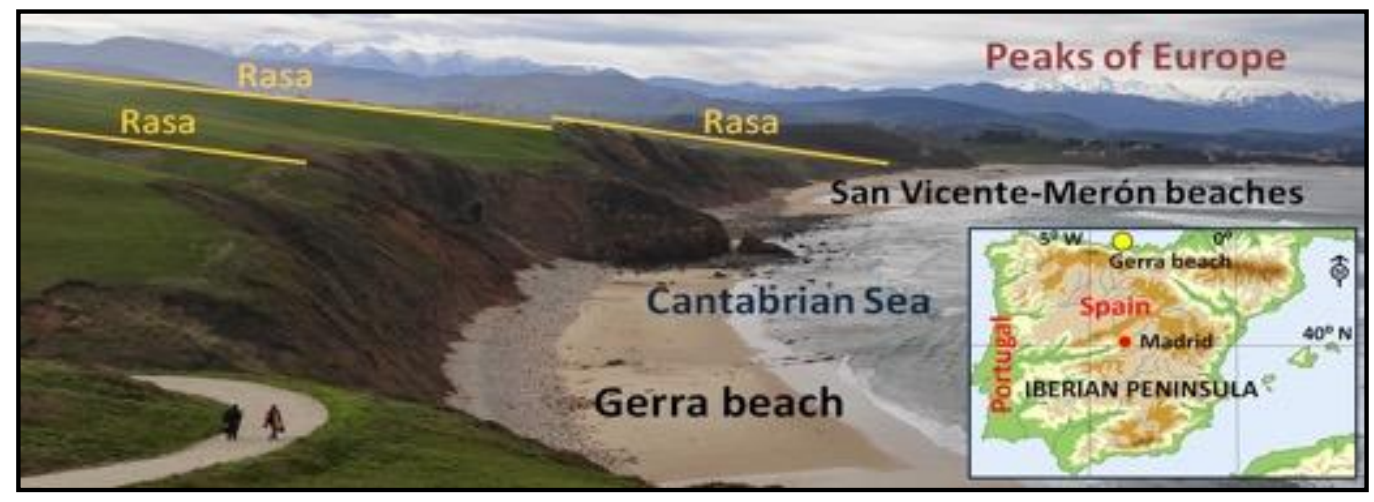

Figure 1. Gerra beach and San Vicente-Merón beaches system from the east of abrasion platform "rasas".

Gerra beach is located at the north facing sea cliff in the eastern part of the San Vicente-Merón beaches system (formed by El Rosal Beach, Merón Beach, Bederna Beach, and Gerra Beach), protected by the West Point (or Merón Point) and located $700 \mathrm{~m}$ NW towards Gerra village. The study site is only a part of the San Vicente-Merón beaches system (Figure 1), which is a tourist beach which extends for $3 \mathrm{~km}$. It is an important focus for surfers and bathers, who have access to the beach by a dirt road, but human influence is restricted to a minimum and the cliffs are unprotected.

Gerra beach $\left(43^{\circ} 24^{\prime} 03^{\prime \prime} \mathrm{N}, 4^{\circ} 21^{\prime} 18^{\prime \prime} \mathrm{W}\right)$ is a composite beach with sea cliff. Therefore, the beach consists of an upper backshore composed of cobbles and boulders, and a foreshore of sand modeled 
by the waves and nearshore and offshore currents. The onshore cliffs rise to a maximum height of $40 \mathrm{~m}$ above the Cantabrian Sea. In the areas of Gerra and San Vicente-Merón beaches, it is possible to differentiate the following three old sea levels: two "rasas" at 40-60 m and 65-75 m height and one small level located at 5-6 $\mathrm{m}$ height $[34,37,39]$. On the beach, depositional sequences have been described consisting of basal gravels, clays, and eolian sands related to sea level changes and dated as glacial (Figure 1) [34] and preglacial age (71,570 \pm 13,400 years BP) [40]. Along the San Vicente-Merón beaches, naturally driven mass movements are a frequent phenomenon [37,40] of various magnitudes, from 0.05 to 1 ha. Processes located on the cliff are minor rock falls and slope landslides, ranging in magnitude with volumes of several thousand of $\mathrm{m}^{3}$. Such slope instabilities have recently affected the cliff top settlements of the El Puntal neighborhood (Figure 2), a new housing development and road. The sea cliffs of Gerra beach are composed of two areas with different characteristics. The east side is formed by two turbiditic geological units (Figure 2).

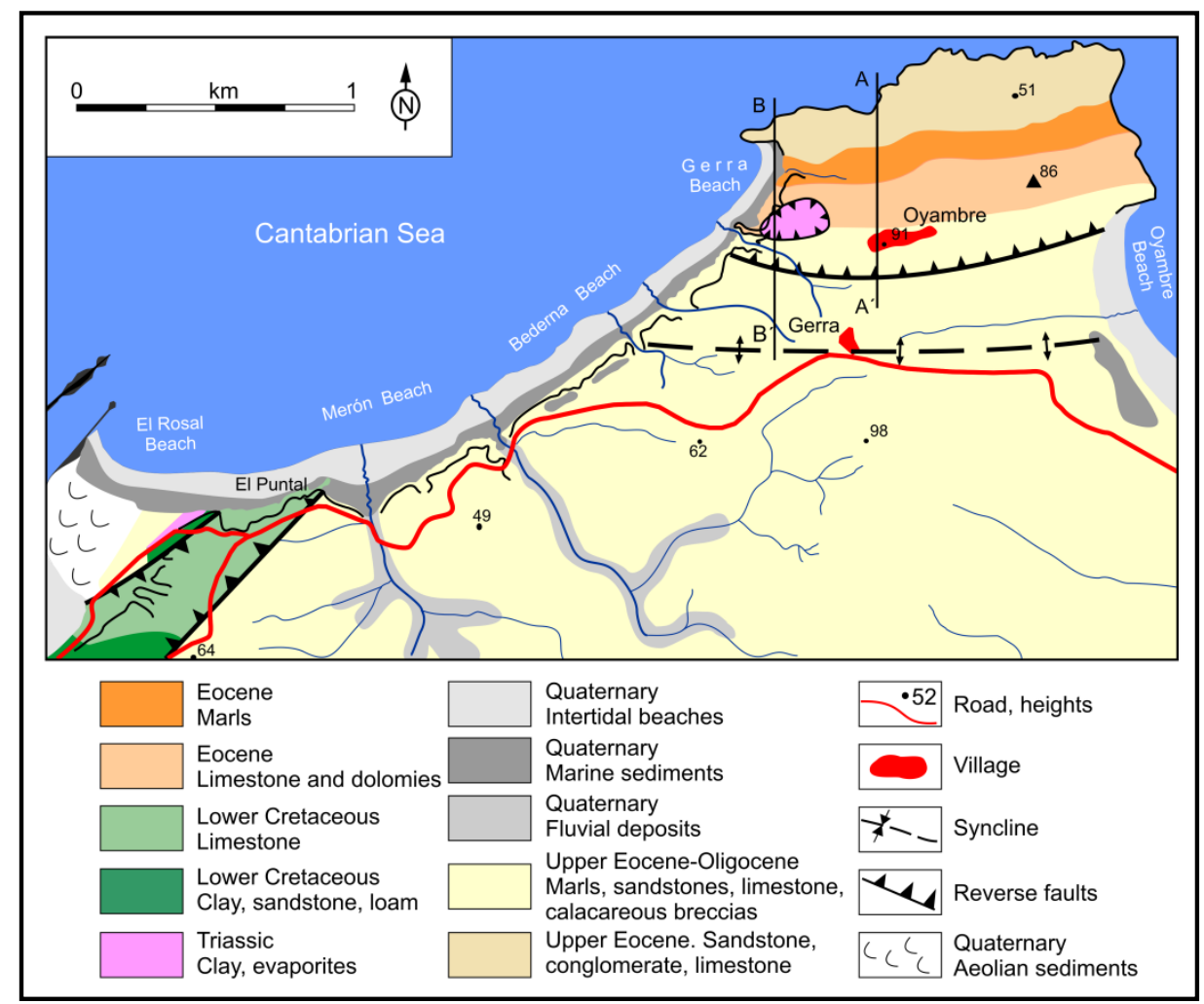

Figure 2. Geological schematic of the SanVicente-Merón coastal system [41,42].

Historic data and field evidences have shown that cliff erosion and landslide mode have been controlled by geology, as [43] noted in other coastal areas of northern Spain. The steeply inclined turbidic cliff sections have mainly collapsed due to sudden falls and landslides along structural discontinuities, such as joints or stone beds. This has led to small rock falls, and clay flows with volumes reaching between 500 and $2500 \mathrm{~m}^{3}$.

\section{Data Acquisition and Methodology}

In order to measure the retreat at Gerra beach, we began by digitizing orthophotos from 1956 obtained from the American Flight of the Iberian Peninsula, available on the web of Instituto Geográfico Nacional (IGN, National Geographic Institute). Using the photogrammetric flights from 2001, 2005, 2010, 2014, and 2017, maps, at a scale of 1:5000, were made through stereophotogrammetry. A LiDAR (light detection and ranging) flight from IGN, dating from the summer of 2012, was considered, as well as an unmanned aerial vehicle (UAV) flight completed in November 2018. A significant quantity 
of data was obtained with a terrestrial laser scanner (TLS) since surveys were made on the beach twice a year. These TLS observations began in 2012 and continued uninterrupted to the present (last one in March 2020).

\subsection{Aerial Acquired Data (1956-2018)}

The existent photogrammetric flights over Gerra beach date from 1956 (B-series of the American Flight of the Iberian Peninsula), 2001, 2005, 2010, 2014, and 2017. The 1956 flight has no calibration certificate available, but the corresponding orthophoto generated by the IGN does exist. In this orthophoto, the dividing line between the upper part of the sandy slope and the stable zone of the surrounding plots is evident (Figure 5a). Therefore, this upper line of the sandy slope has been represented by digitizing it in the orthophotography. Obviously, the 1956 flight does not have the same precision as the subsequent photogrammetric flights, but its digitization allowed us to have baseline beach information from 1956 [44].

From the other flights, all originating from the Plan Nacional de Ortofotografia Aérea (PNOA, National Plan of Aerial Orthophotography), maps at a scale of 1:5000 were produced. For these flights, camera calibration certificates are available (focal length, fiducial marks coordinates, principal point coordinates). There is also information about each flight. The ground sampling distance (GSD) of the scanned photographs is $0.22 \mathrm{~m}$ and for the orthophotos it is $0.25 \mathrm{~m}$, the planimetric precision is $\leq 0.5 \mathrm{~m}$ for the orthophotos and the altimetric precision for the digital elevation model (DEM) is $\leq 1 \mathrm{~m} \mathrm{[45].}$

A set of 10 ground control points was determined in the official geodetic reference system of Spain (ETRS89) using Leica 1200 GNSS (Global Navigation Satellite System) receivers in real-time kinematics (RTK) modus with postprocessing achieving a positioning precision of $\pm 2 \mathrm{~cm}$. From the 2001, 2005, 2014 and 2017 PNOA flights, maps of the Gerra beach were made. In order to determine the scale that could be used to produce the maps, the coordinates of four check points were measured in the stereo pairs (Table 1). The maximum differences at check points were $\pm 0.99 \mathrm{~m}$ in planimetry and $\pm 0.63 \mathrm{~m}$ in altimetry. Therefore, these values conditioned the scale and the equidistance of contour lines in the map to be produced [46].

Table 1. Check points measured in the photogrammetric models of the different flights. Measured coordinates and maximum differences to ground measured points. Maximum difference of coordinates (photogrammetric restitution) are X (\# 3) $0.99 \mathrm{~m}, \mathrm{Y}$ (\# 2) $0.97 \mathrm{~m}$, and Z (\# 2) $0.63 \mathrm{~m}$.

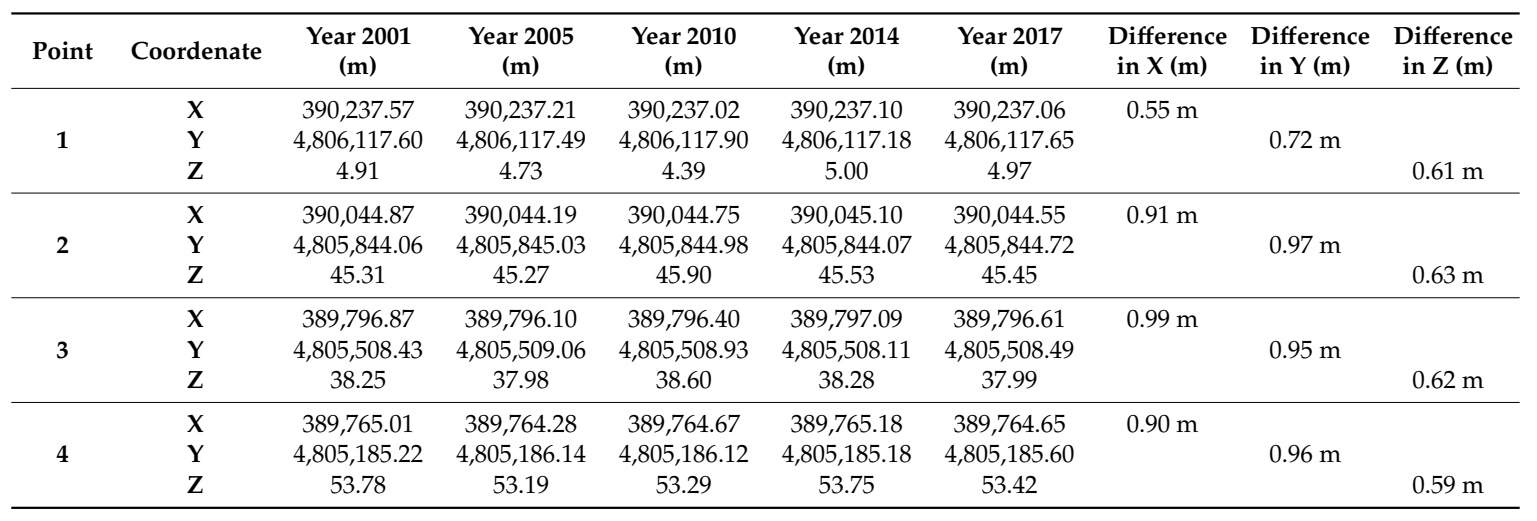

In the summer of 2012, the IGN performed a LiDAR survey of the Cantabrian coast (Gerra beach included) for the PNOA. These flights had a point density of 0.5 points $/ \mathrm{m}^{2}$ and the point clouds had a planimetric/altimetric mean square error of RMSE $x, y$, and $z \leq 0.2 \mathrm{~m}$.

To complete the map series of the project, a UAV photogrammetric flight was done in November 2018, using an eBee Classic from SenseFly. The eBee is a fixed wing UAV equipped with a calibrated Sony VX RGB camera with a $6.16 \times 4.63 \mathrm{~mm}$ sensor, $18.2 \mathrm{Mp}$ resolution, and $4.57 \mathrm{~mm}$ focal length. 
The flight was planned with forward and side overlap of $80 \%$ between photographs, at a flying height of $100 \mathrm{~m}$ adapting to the terrain through the geoid model STM. The software eMotion Version 3 from SenseFly was used for flight planning. According to the camera parameters and the flight plan, the expected GSD was $2.75 \mathrm{~cm}$. A total of 173 images were obtained. Previously, 20 ground control and check points were measured using a GNSS Leica 1200 in RTK modus, with corrections from the real-time positioning service of the IGN from the network solution and a RMSE $x, y$, and $\mathrm{z} \leq 20 \mathrm{~mm}$ was achieved.

The images were photogrammetrically processed with the Pix4D Mapper pro version 3.1.18 software. The predefined configuration in the software was used to process the photogrammetric surveys carried out with UAVs. The relative orientation of the model started from the position of the cameras given by the metric GNSS system loaded in the UAV and an adjustment of the position of the cameras was performed by running the calculation algorithm of the software itself. The absolute orientation was done by measuring the ground control points of the model in the images. From this orientation, an optimization of the parameters of the relative orientation was carried out depending on the control points. Twenty ground control and check points were used and a model with RMSEx $\leq 4.2 \mathrm{~cm}$, RMSEy $\leq 2.9 \mathrm{~cm}$, and RMSEz $\leq 3.6 \mathrm{~cm}$ was obtained. The distribution of the control and check points was mostly in the beach area (Figure 3). Once the photogrammetric model was defined, the dense point cloud and the orthoimage were obtained as cartographic products necessary for our research.

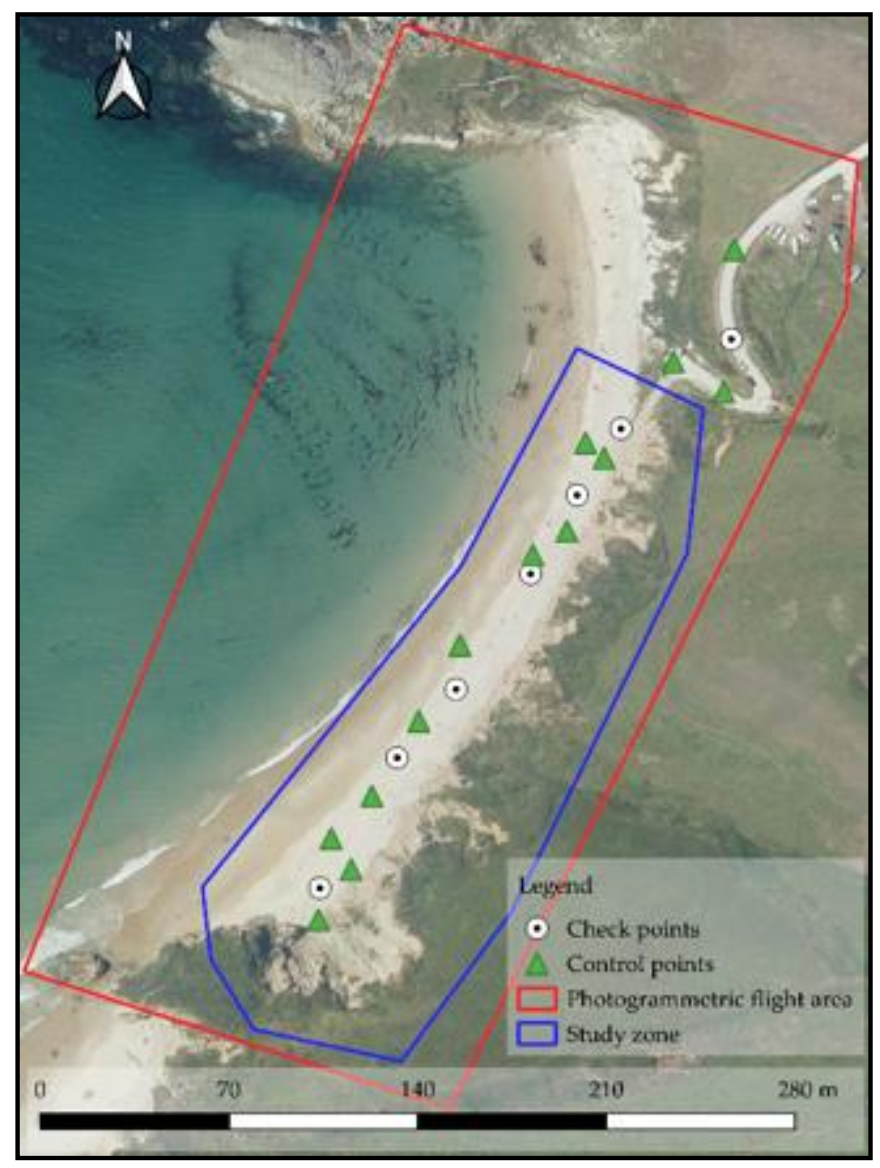

Figure 3. Distribution of the control points for the unmanned aerial vehicle (UAV).

\subsection{Terrestrial Laser Scanning Data (2012-2020)}

The application of terrestrial laser scanning (TLS) for monitoring and analyzing geomorphological dynamics on sandy coasts with millimetric precision is relatively recent and very efficient even at 
detecting annual changes [47], as well as complementing traditional analytical methods. TLS has functional sensitivity under adverse meteorological conditions [48] and a versatility that permits monitoring at any time. Its reliability has been proven on the coasts of the Cantabrian Sea in the study area, on confined beaches nearby, and in the ongoing observation of sand banks [11,49]. The scanner measured the three-dimensional (3D) position of data points in the survey area, the $x, y$, and $z$ coordinates, and also collected the reflection intensity of each point [17]. The spatial position accuracy of the points measured with the Leica Scan Station C10 was given as $\pm 6 \mathrm{~mm}$ at a distance of $100 \mathrm{~m}$, although this value could increase, influenced by the type of element in the cliff that reflected the laser pulse (for instance, moving vegetation during measurement). This uncertainty added to the positioning error of the targets which was determined by GNSS $( \pm 20 \mathrm{~mm})$ and yielded an estimated position uncertainty $\leq 3 \mathrm{~cm}$. Then, the spatial point information of the resulting point cloud could be used to derive accurate digital elevation models (DEMs) [50,51].

Since May, 2012, until the present, TLS surveys have been made twice a year, in spring (April-May) (Figure 4a) and in the fall (October-November) (Figure 4b), in order to be able to obtain 3D data of Gerra beach before and after the winter storms of the Cantabrian Coast.

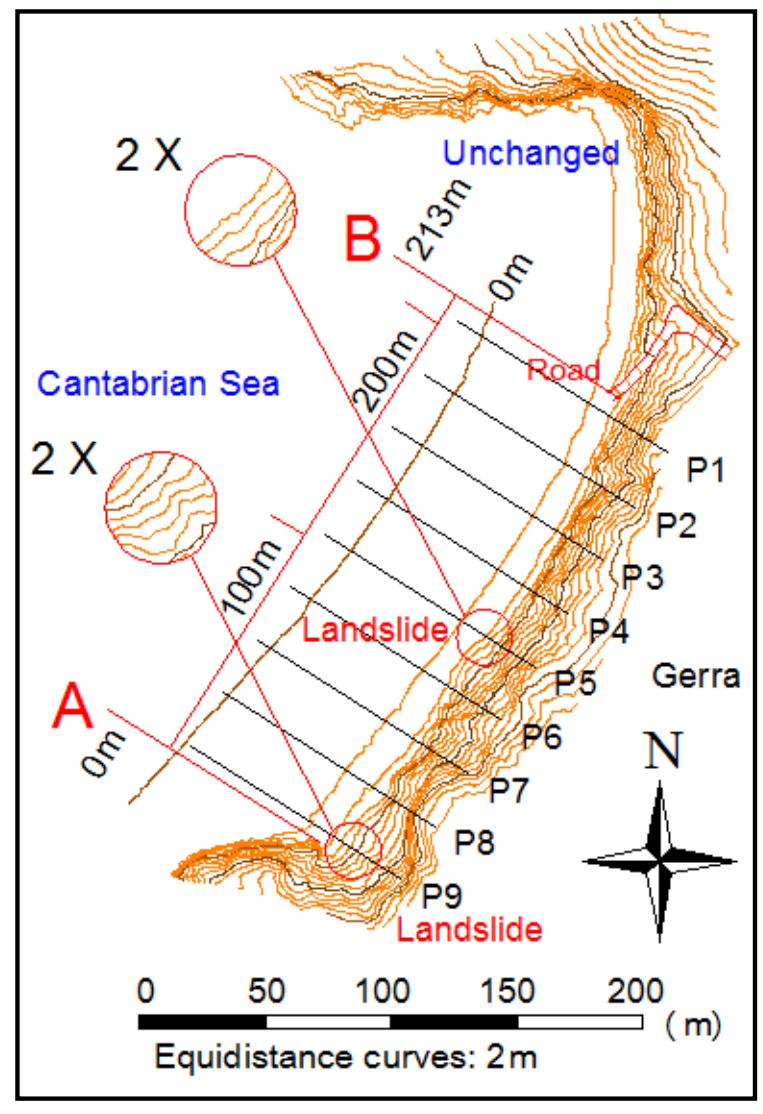

(a)

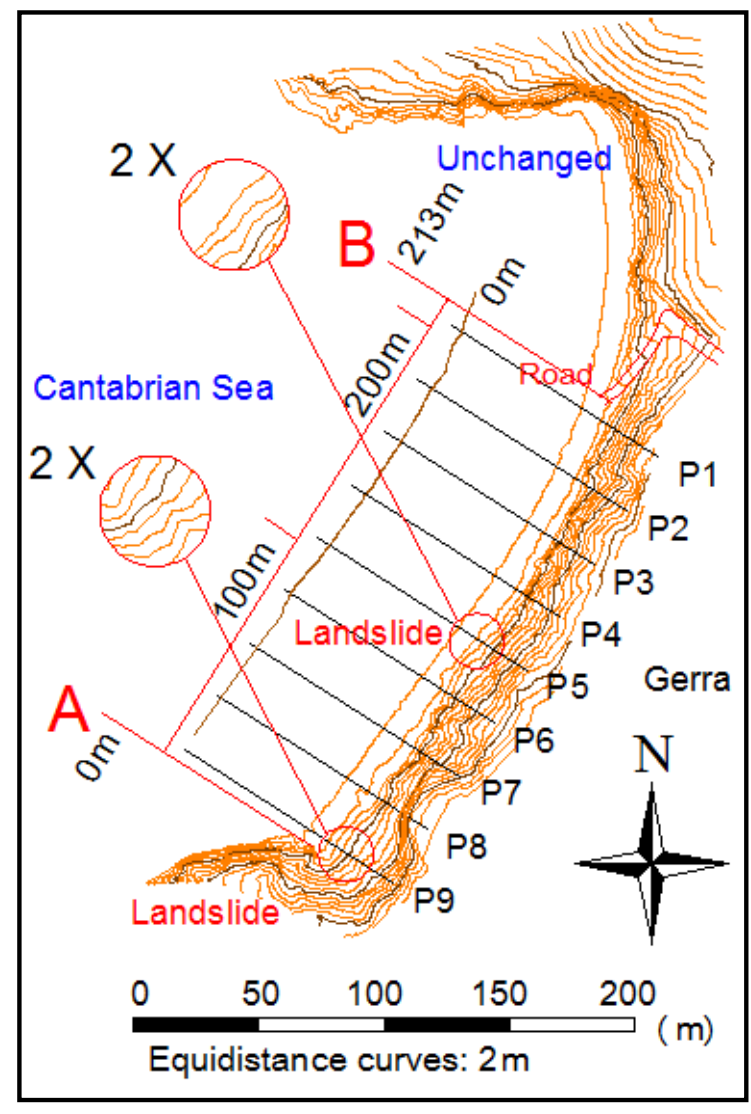

(b)

Figure 4. Indication of the most significant landslide zones (red circles) according to terrestrial laser scanner (TLS) surveys of Gerra beach. (a) Digital elevation model (DEM) of October 2018; (b) DEM of April 2019.

In each campaign, six or seven scans were performed using at least 4 targets to register neighboring scans. The whole point cloud contained more than 250 million points. With the point clouds, DEMs were generated. Difference models for specific periods were later calculated by comparing successive point clouds and surface models. In addition, nine profiles (P1, ..., P9) were also determined. This procedure 
provided visualization of areas subject to temporal surface changes, and therefore permited monitoring and quantifying changes.

\subsection{Analysis Evolution of the Beach and Coastline on the Top and Toe of the Cliff}

To compare the upper and lower coastlines of the sandy slope, a 1/5000 scale map was made from the aerial photographs of the PNOA flights by stereophotogrammetry. With this scale, a planimetric error tolerance of $1 \mathrm{~m}(0.2 \mathrm{~mm}$ times the scale denominator) and an equidistance between contours of $2 \mathrm{~m}$ (1/3 of the contours equidistance allowing maximal errors of $0.67 \mathrm{~m})$ was obtained. This means that, in the produced maps, the probability of obtaining planimetric accuracy better than $1 \mathrm{~m}$ and altimetric accuracy better than $0.67 \mathrm{~m}$ was very low. These errors were bigger than those estimated for LiDAR (maximum error $\pm 20 \mathrm{~cm}$ ), for TLS (maximum errors of $\pm 3 \mathrm{~cm}$ ), and for UAV surveys (maximum errors of $\pm 4 \mathrm{~cm}$ ), indicating that the map representations defined the method with less accuracy for the present purpose (Table 2).

Table 2. General information of initial data and obtained results for Gerra beach.

\begin{tabular}{cccc}
\hline Date (Year) & Information & Maximum Error (m) & Result \\
\hline 1956 & Ortophotography & $2 \mathrm{~m}$ & Digitization \\
200-2005-2010-2014-2017 & Aerial & $1 \mathrm{~m}$ & $\begin{array}{c}\text { Cartography by restitution } \\
\text { photogrammetric }\end{array}$ \\
August 2012 & photogrammetry & $0.20 \mathrm{~m}$ & DEM \\
November 2018 & LiDAR & $0.04 \mathrm{~m}$ & DEM \\
2012-2020 (Semiannual & TLS & $0.03 \mathrm{~m}$ & DEM \\
measurements, spring and fall) & & & \\
\hline
\end{tabular}

With the other of the techniques used in this project (LiDAR, UAV, TLS), the upper and lower coastline of the sandy slope were not extracted. From the generated DEMs (LiDAR, UAV, TLS), different DEMs and profiles were made in order to study the evolution of the cliff. Currently, there is only one LiDAR flight in the north of the Iberian Peninsula (summer of 2012), belonging to the IGN public body. As for UAV, there was only the information of one flight (November 2018). With TLS, two measurements per year were performed (spring and fall) for the period 2012-2020, and the respective DEMs were generated, nine parallel profiles $25 \mathrm{~m}$ apart and perpendicular to the coastline were extracted, and their evolution studied (Table 2).

\section{Results}

\subsection{Applying Aerial Photogrammetry (1956-2017)}

Through analyzing the digitized top and toe lines of the 1956 and the five maps done by photogrammetric methods for the (2001-2017) period, no significant height changes were detected (Figure 5). The planimetric elements that were extracted from the map were the road for the access to the beach and the cliff top line, as well as the contour of the landslides (Figure 6a). The height contours were also represented with an equidistance (normal curves) of $2 \mathrm{~m}$ and master curves every $10 \mathrm{~m}$. 


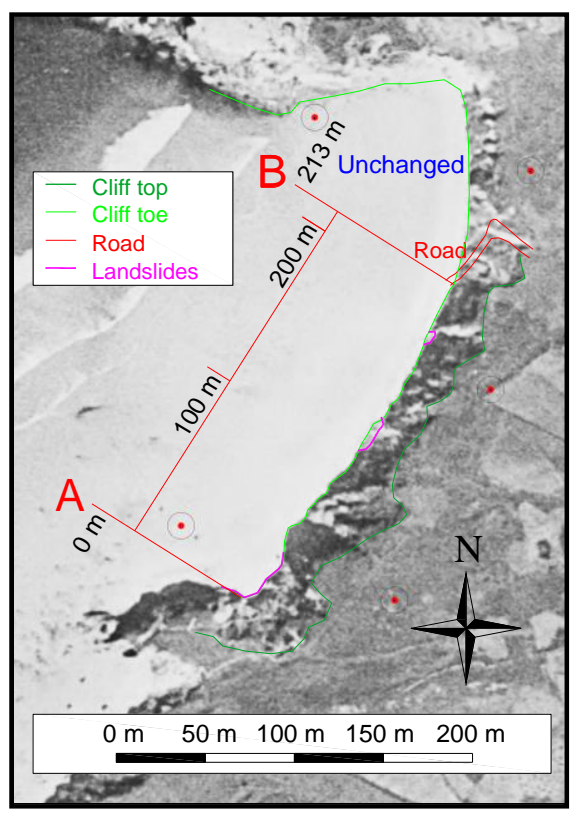

(a)

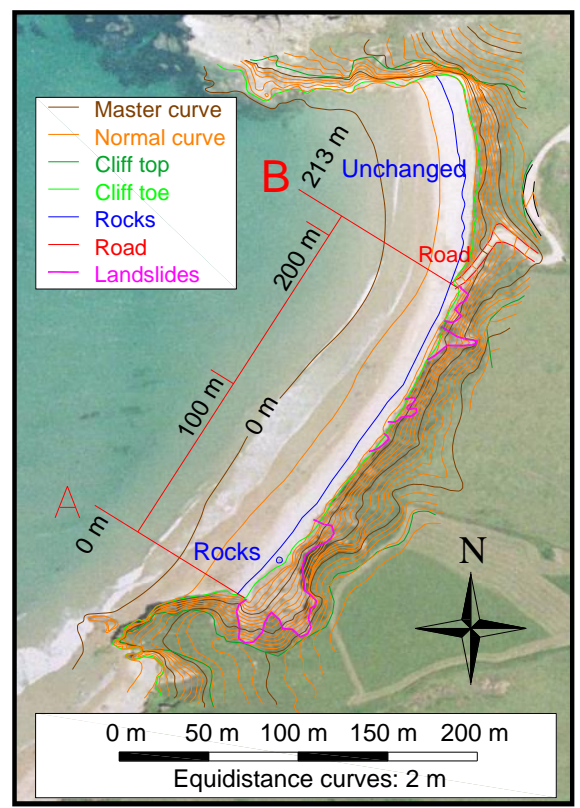

(c)

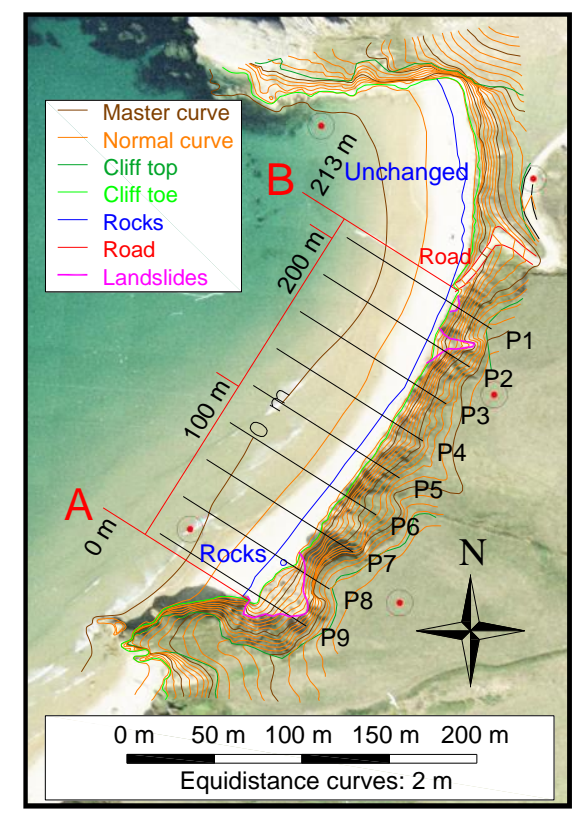

(b)

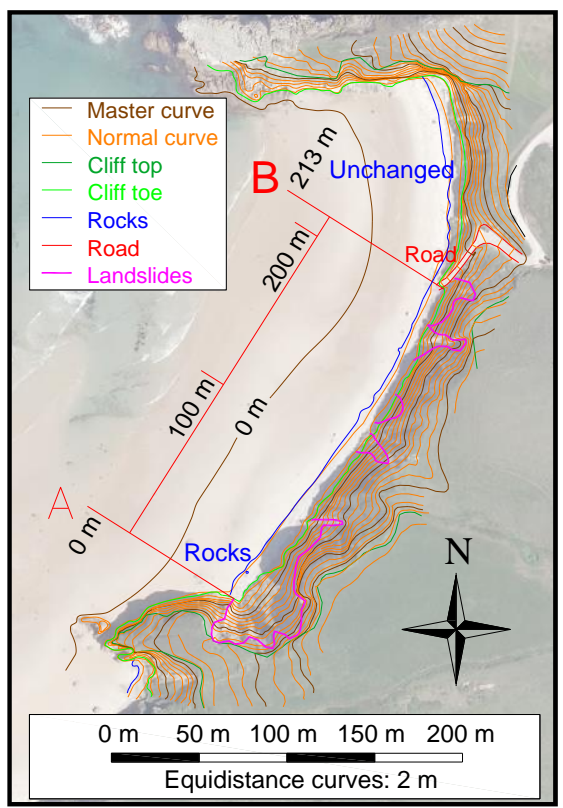

(d)

Figure 5. Cont. 


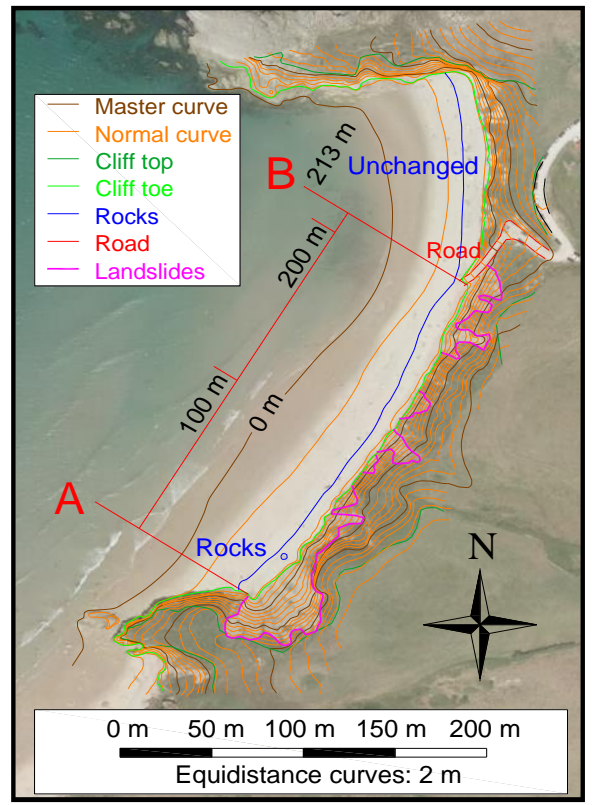

(e)

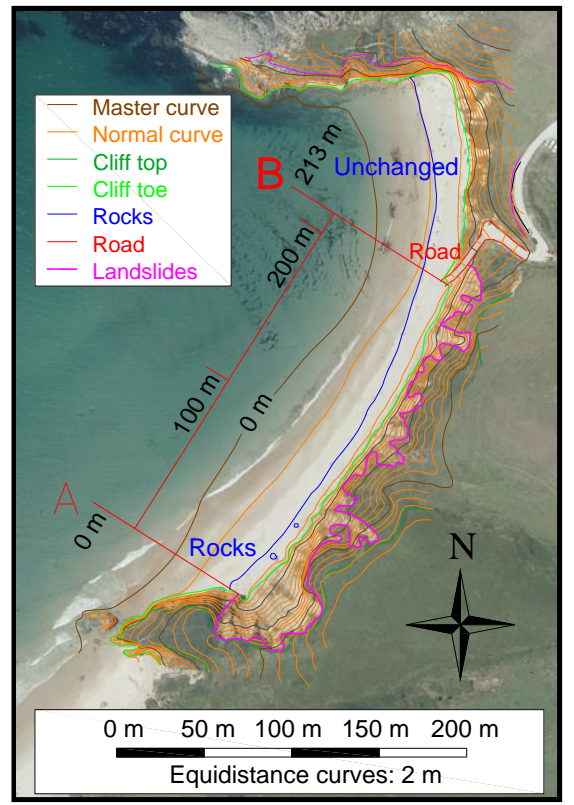

(f)

Figure 5. (a) Delimitation of the coastline in the orthophoto of the American flight (1956). DEMs (height contours every $2 \mathrm{~m}$ ) for the years (b) 2001; (c) 2005; (d) 2010; (e) 2014; (f) 2017.

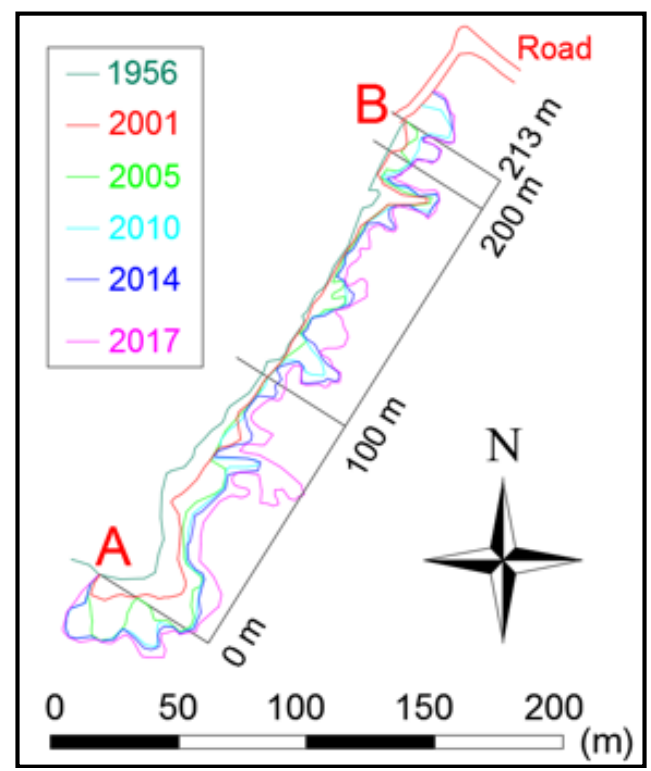

(a)

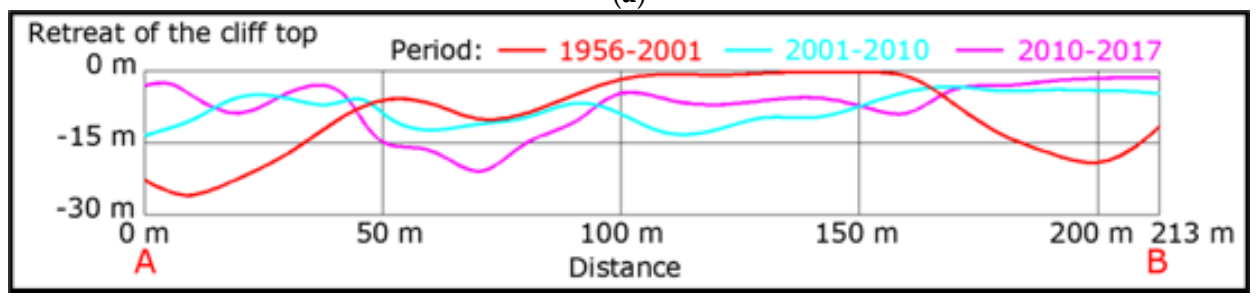

(b)

Figure 6. (a) Evolution of the cliff top between A and B. Lines of the years 1956, 2001, 2005, 2010, 2014 and 2017; (b) Comparison of the retreat of the cliff top in the periods 1956-2001, 2001-2010, and 2010-2017. 
The retreat of the cliff baseline was not very meaningful for the occurring process, since there were no big changes during the analyzed period. The same cannot be said regarding the cliff top line, where landslides took place and significant retreat values could be determined. Therefore, the extracted cliff top lines (line A-B of $213 \mathrm{~m}$ ) from the 1956 orthophoto and from the photogrammetric plotting were compared and the evolution graphics were produced for the following periods: 1956-2001, 2001-2010, and 2010-2017 (Figure 6b). For the three periods analyzed (1956-2001, 2001-2010, and 2010-2017) the upper horizontal line (retreat of the cliff top, $0 \mathrm{~m}$ ) indicates the initial position of the cliff top line for the year of origin of each period (1956, 2001, and 2010). The curved lines (red, blue, and purple) represent the differences between the situation of the cliff top line between the oldest and the most recent date in each period. In all cases, the cliff top line is pushed inland.

\subsection{Applying Light Detection and Ranging (LiDAR) (August 2012) and Unmanned Aerial Vehicle (UAV) (November 2018)}

Collecting the available information from the 2012 LiDAR flight, the cartography was made with an equidistance of 4 meters (normal curve). The $0 \mathrm{~m}$ height contour from the TLS survey of April 2012 was incorporated. The location of the beach access road was also represented (Figure 7a).

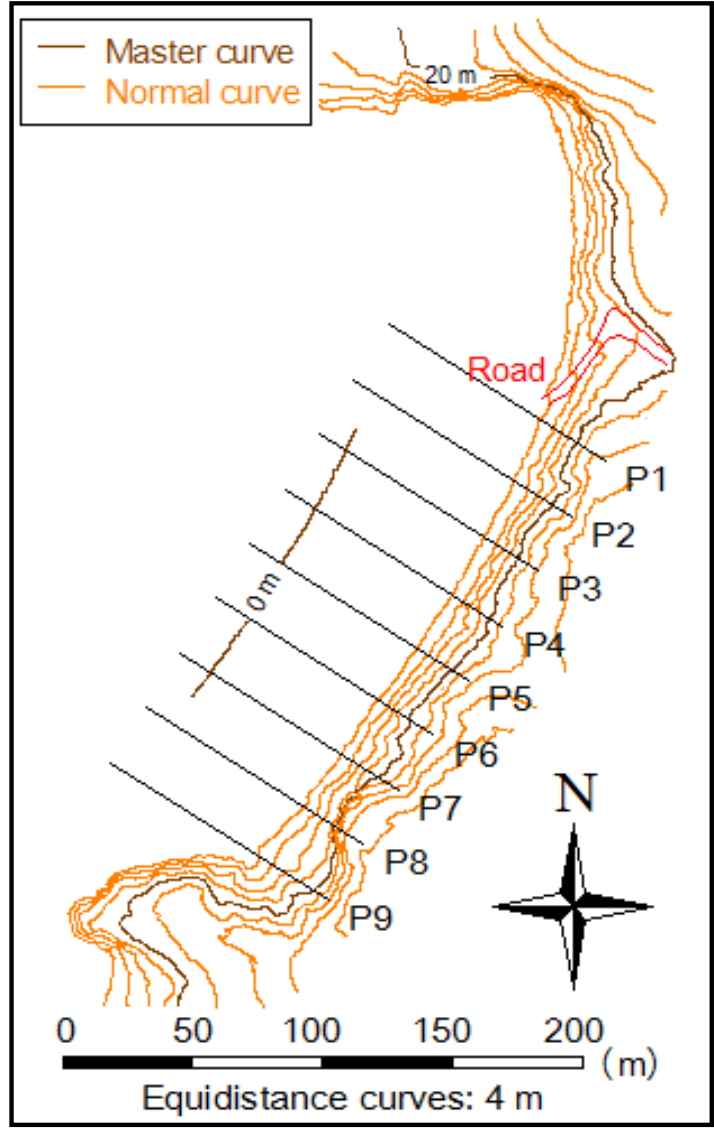

(a)

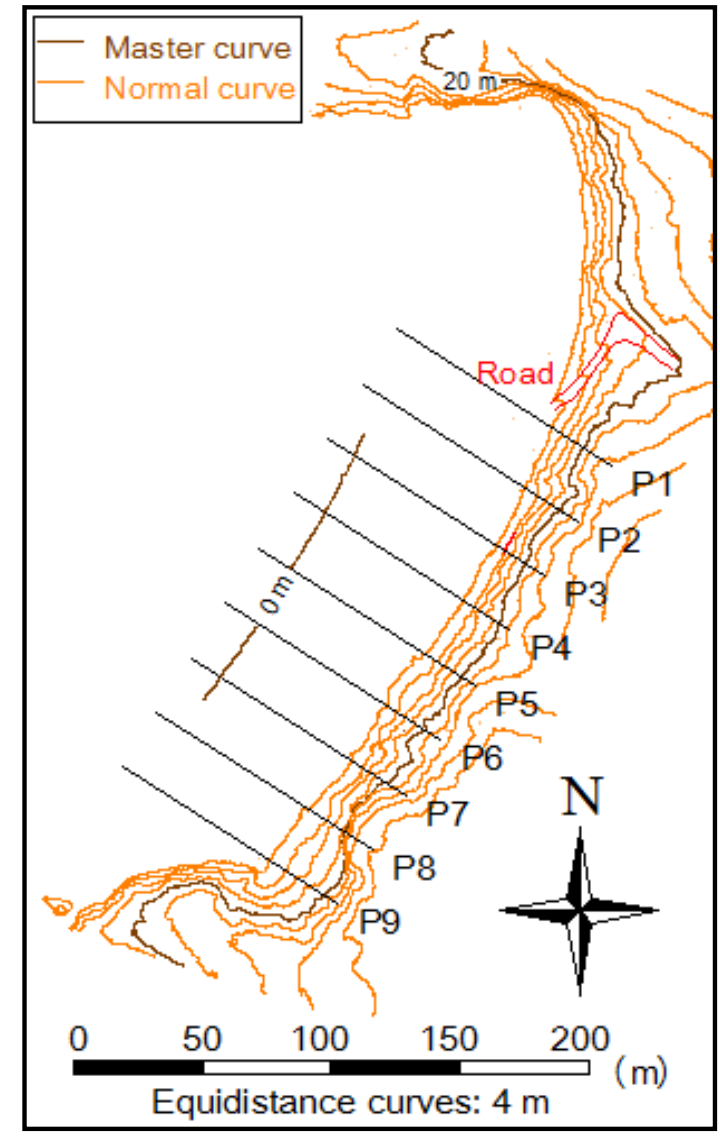

(b)

Figure 7. Cont. 


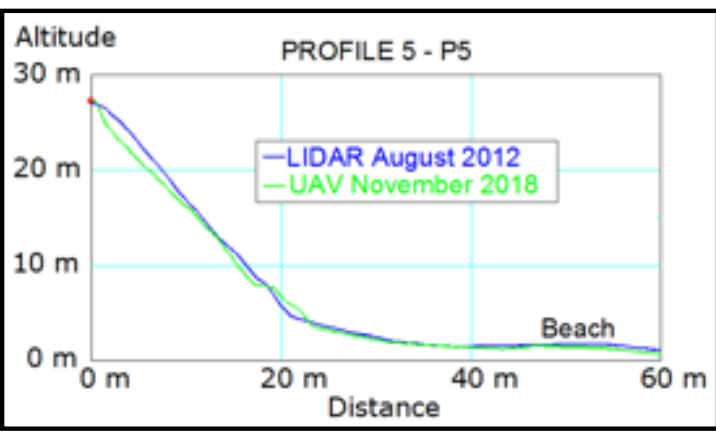

(c)

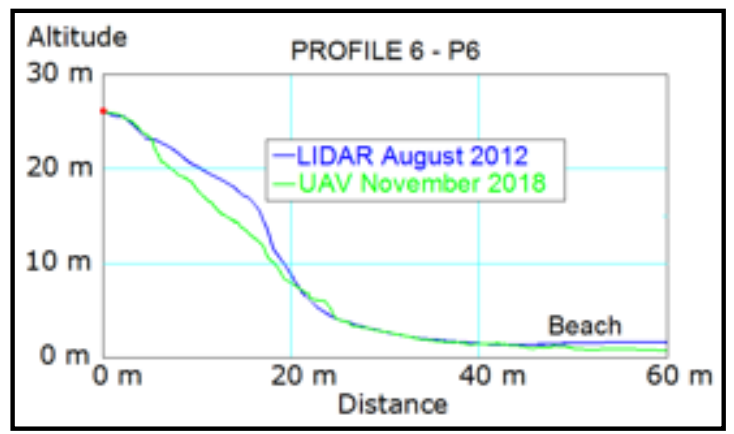

(d)

Figure 7. (a) Cartography light, detection, and ranging (LiDAR) (National Geographic Institute (IGN)) (August 2012); (b) Height contours from DEM of UAV (November 2018); (c) Comparison of Profile 5 from LiDAR and from UAV; (d) Comparison of Profile 6 from LiDAR and UAV.

From the results of the UAV flight, the height contours were interpolated from the DEM and the most significant elements of planimetry were obtained by digitization, representing the base and top line of the cliff, landslides, and access road. Later, an orthophoto mosaic with a GSD (ground sampling distance) of $4 \mathrm{~cm}$ was also done (Figure $7 \mathrm{~b}$ ).

To check the variations in the cliff, Profile 5 (P5) and Profile 6 (P6) (Figure 7c,d) were selected from those indicated in Figure 7a,b. While in P5 there was a small landslide during this period, in P6 there was a large landslide, specifically between autumn 2017 and spring 2018 (Figure 9). In the beach area, there were hardly any variations in elevation for these two dates, although the measurements carried out every six months verified a variation in the elevation (Figure 8).

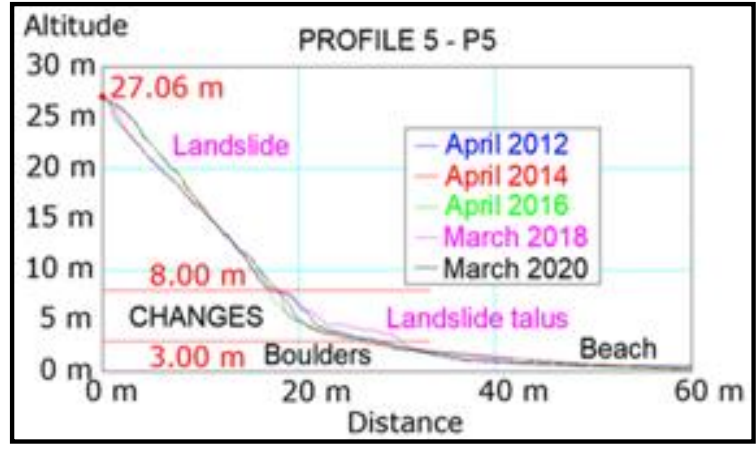

(a)

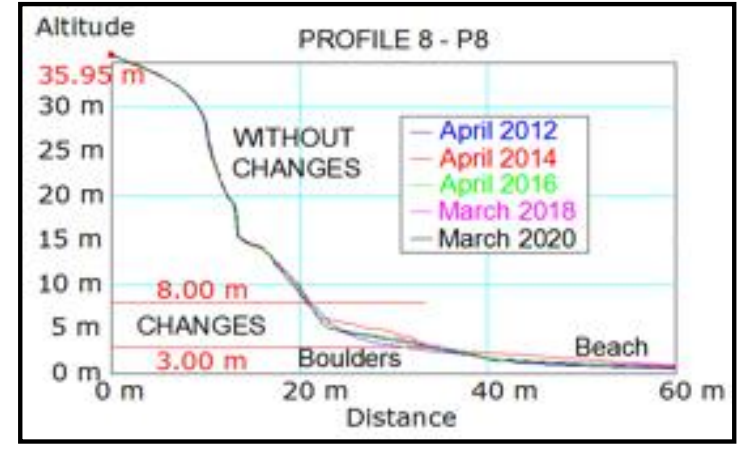

(b)

Figure 8. Cliff profile evolution between the more significant campaigns. (a) Profile 5 shows a landslide that occurred in March 2018; (b) Profile 8 contains a rocky substrate.

\subsection{Applying Terrestrial Laser Scanning (2012-2020)}

In Figure 8, two profiles are drawn (P5 and P8), P5 is a typical profile of the cliff, but in March 2018 there was a landslide there (Figure 8a). Profile P8 has a rocky substrate, and therefore is very stable (Figure $8 \mathrm{~b}$ ). There was a set of 17 TLS surveys (2012-2020), therefore, for each of the profiles (P1 to $\mathrm{P} 9$ ) the respective heights were extracted from the 17 DEMs produced from the surveys. In Figure 8, however, only the initial (2012) and the final (2020) situations are shown together with the corresponding years when there were significant differences between successive profiles $(2014,2016$, and 2018). The profiles corresponding to non-significant changes between surveys are not represented. These changes mainly occurred at an altitude above the mean sea level between 3 and $8 \mathrm{~m}$, since this was the area hit by the waves. 
During the measurement period with TLS (2012-2020), the stability of the cliff was verified, despite the occurrence of storms on the Cantabrian coast. In fact, in the winter of 2013 there were four major storms [38], and therefore it was expected that large changes could be detected between the measurement of November 2013 and April 2014. However, although there were changes, the changes were not of the magnitude of what happened on other Cantabrian beaches [12,38]. The erosion of the cliff was more significant after the winter period, detected in the TLS observations of March or April (spring), and especially in 2014, 2016, and 2018 (Figure 8).

In addition to the profiles, the DEMs produced from the TLS survey data were also analyzed. Regarding the interpretation of the volumetric evolution of the DEMs, shown in Figure 9, we deduced the following:

- In general, the semiannual altimetric variations were within the interval of 0 to $\pm 0.5 \mathrm{~m}$. In rare situations there were differences between \pm 0.5 and $\pm 1 \mathrm{~m}$, and differences higher than $\pm 1 \mathrm{~m}$ are very rare.

- Small and large landslides were detected in DEMs. Large landslides, in some cases were caused by storms, for example, between the fall of 2013 and the spring of 2014; in other cases, the landslides were caused by the instability of the cliff.

- The total accumulated volume in the study area (beach and cliff), from the spring of 2012 to the present (April 2020), indicated a material gain of $399.66 \mathrm{~m}^{3}$. It was a very small, almost negligible, gain value for the eight-year period. But, depending on the campaigns, there could be greater differences (gains or losses) in the beach area. Thus, for example, on the one hand, between the spring of 2016 and the fall of 2016, there was a sand gain of $3467.39 \mathrm{~m}^{3}$, and on the other hand, between the fall of 2015 and the spring of 2016, there was a sand loss of $-3040.04 \mathrm{~m}^{3}$.

- The volumetric values that occurred above the base line of the cliff ( 3 meters above sea level) were also analyzed. At 3 meters altitude, small landslides occurred (for example, between the fall of 2013 and the spring of 2014). There were also large landslides across the cliff (for example, between the fall of 2017 and the spring of 2018). Throughout the study period, the total loss of material that occurred in the cliff area was $-3633.32 \mathrm{~m}^{3}$.
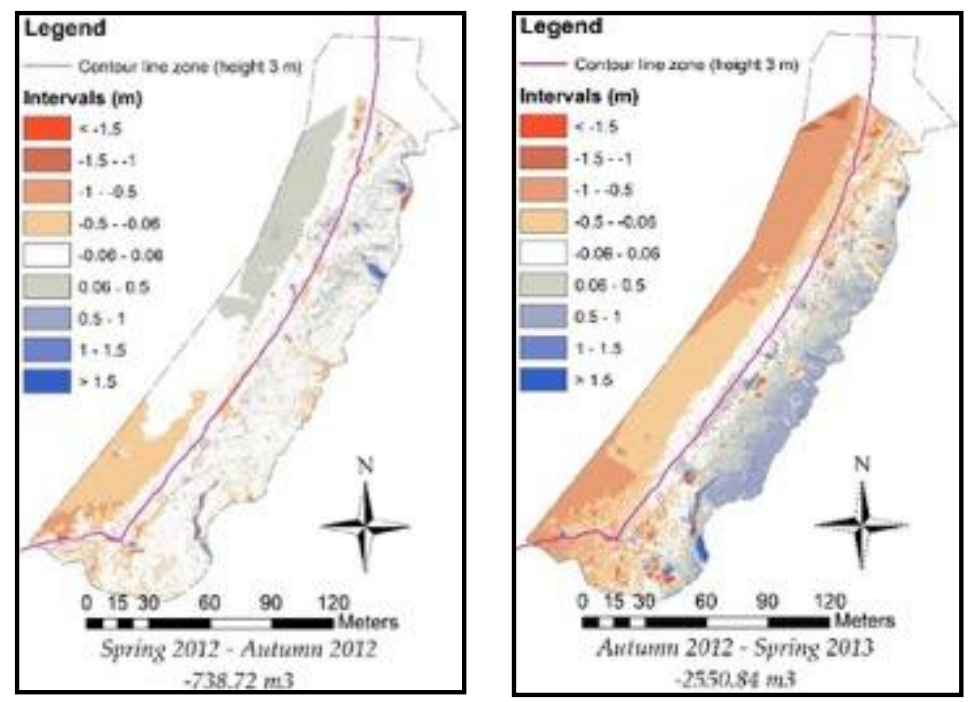

Figure 9. Cont.

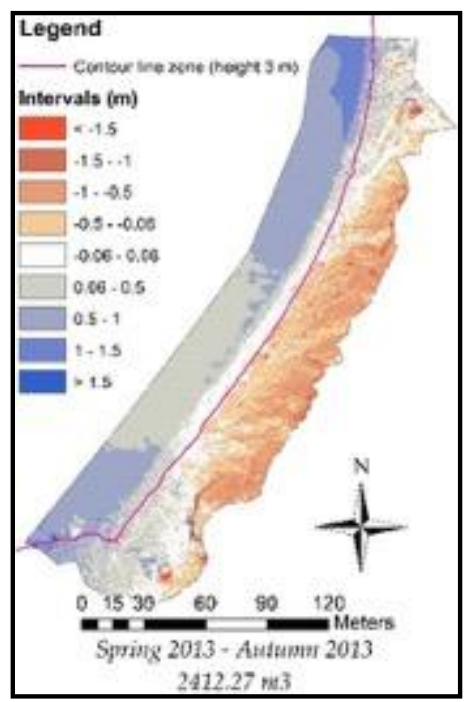

$2412.27 n+3$ 

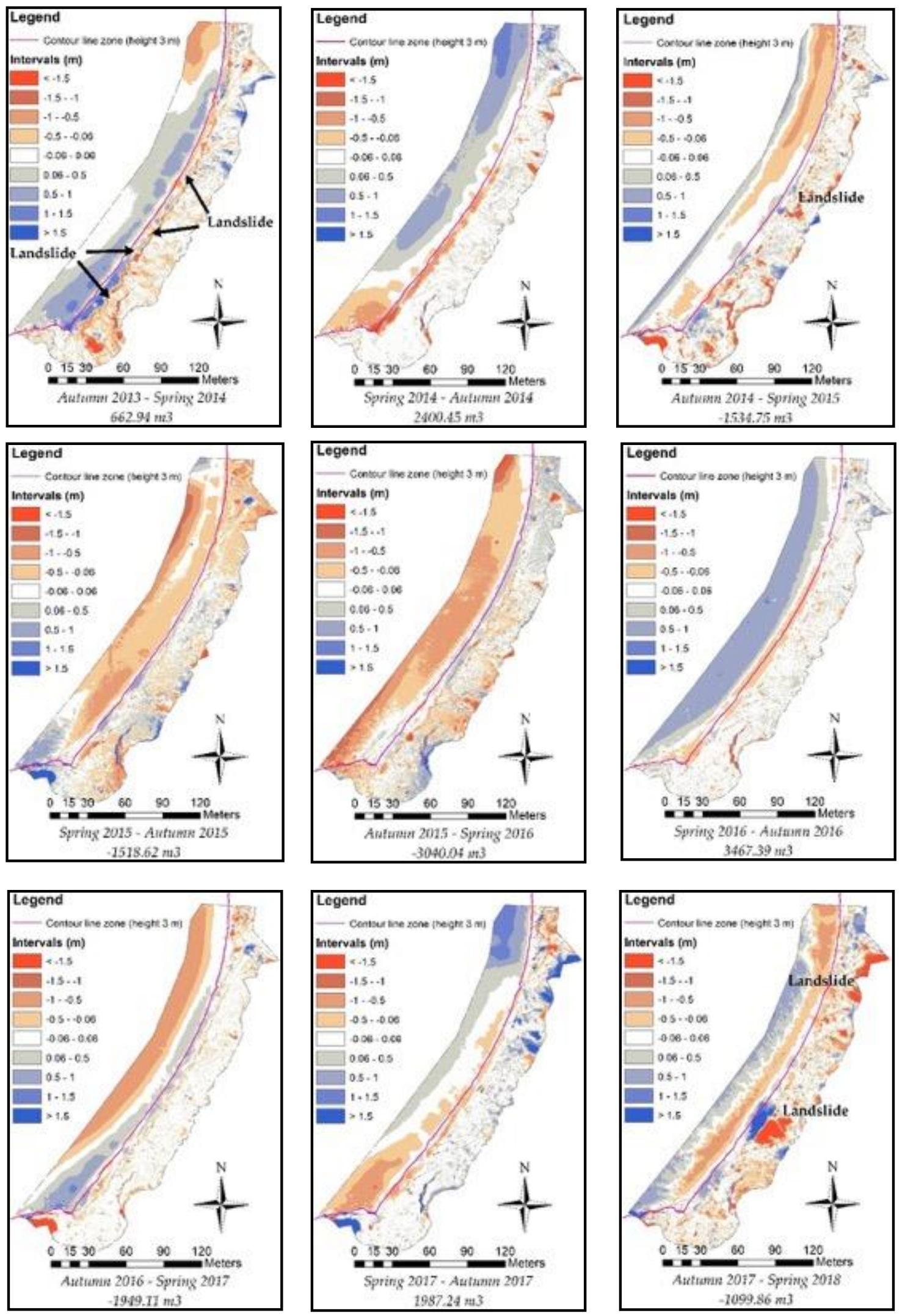

Figure 9. Cont. 

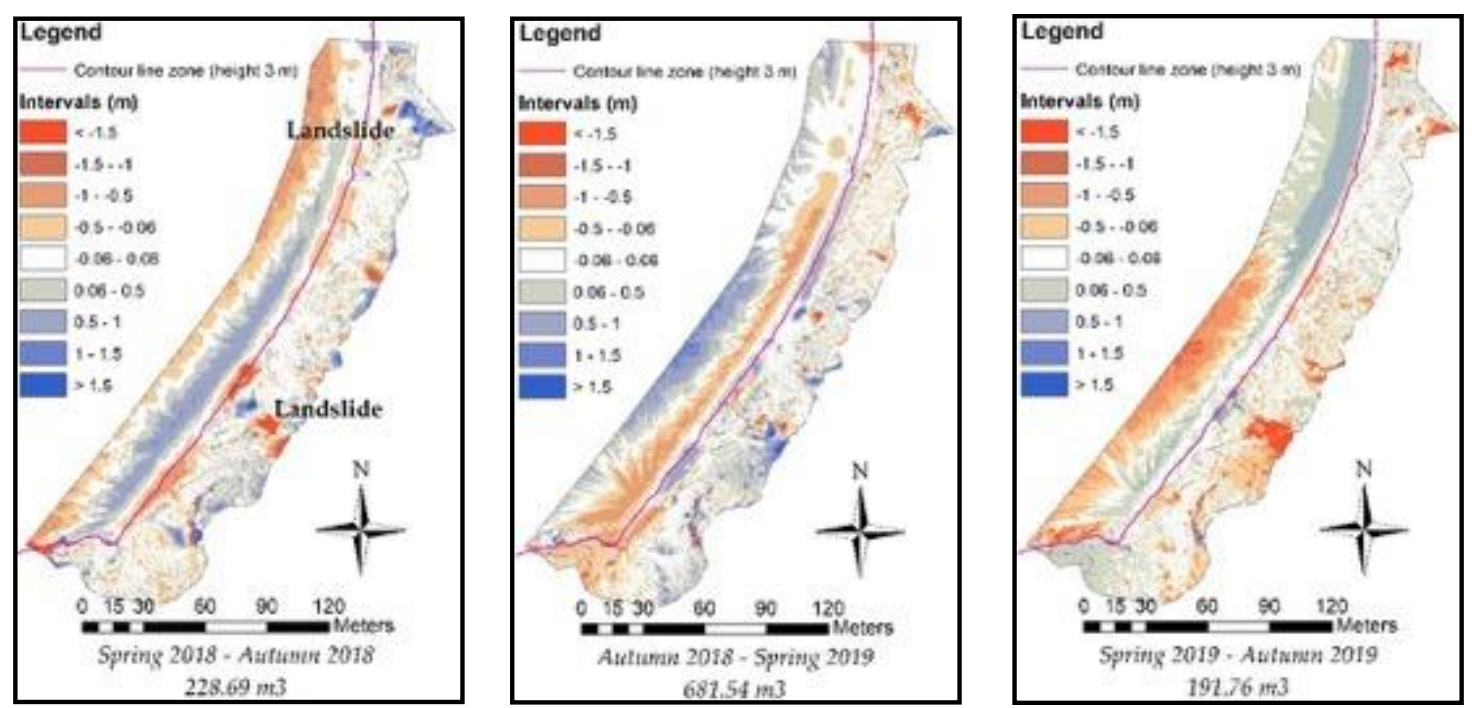

Figure 9. Volumetric evolution between the spring of 2012 and the fall of 2019.

\section{Discussion}

Factors related to cliff behavior are the same on the Atlantic and Pacific coasts. Landslides on the cliff face, the geological structure and lithology, and the location of alternating claystone, sandstone, and limestone imply important differential erosion, and finally, sea exposure [3,5]. Furthermore, on European coasts, the dominant influence of precipitation, in a humid climate with more than $1000 \mathrm{~mm} /$ year, is a determinant factor in cliff top evolution and groundwater level [3]. Contact between claystone and turbiditic facies implies water drains quickly from the top of the cliff and the claystone becomes saturated, causing landslide and rock fall.

Changes in the three sectors of the sea cliff, top, base, and face, can differ significantly over short time periods. On analogous cliffs formed by claystone and sandstone, it is possible that wave action can cause cliff base retreat, but no cliff top change, and also the cliff face erosion can occur without changes to the cliff top or base [4]. In Gerra beach, between 1956 and 2001 (45 years) the retreat occurred mainly in the area of the beach access road, possibly caused by its construction, since, in 1956, it was a very narrow dirt road, and now it is a larger asphalt road. The road building generated artificial slopes and unbalance causing new landslides. Cliff collapses and landslides can be attributed to anthropogenic factors, as seen on the Atlantic coast [3]. During the period 1956-2001 there has also been significant cliff retreat south of the beach (near point A) (Figure 6a), where several landslides are located. In this case is the lithology, a big outcrop of claystone, and the geological structure, the limit of a small diapiric structure, the cause of successive landslides, sometimes occupying the cliff base. The cliff areas with less retreat between 1956 and 2001 were those that have been more intensely affected during the period 2001-2017 (16 years), with average values around $20 \mathrm{~m}$ of retreat (Figure $6 \mathrm{~b}$ ).

During the period 1956-2017, the maximum retreat of the cliff top was $42 \mathrm{~m}$, with the average value for the entire cliff being $25 \mathrm{~m}$. The displacement toward inland of the cliff top was not continuous and the topmost morphology with crowns and main scarps pointed to landslides. A cliff top landslide implies significant recession on top but not necessarily changes at the cliff base because the deposits are quickly removed by wave action prior to subsequent data collection. The elements are both common on the top and face of the cliff when the stratigraphy and the changing lithologies support differential erosion, as has been pointed out in California or Bretagne cliffs [3,5]. Sometimes, advances of the cliff top can happen when landslides are generated in the upper part before they break and fall. In Gerra beach, there was a balance between the offshore and inland displacement. The cliff base appeared to have accreted, although this process occurred very rarely, only when slope deposits were not removed between surveys. 
As the results show, the retreat of the cliff baseline is not meaningful, with small changes during the studied period. On the Atlantic coast, retreat rates of -10 to $-50 \mathrm{~cm} /$ year have been observed $[3,14]$, but these have increased whenever human action was present $[6-10,14,15]$. The retreat rates of Gerra beach are low, in accordance with low human pressure, but this inactivity could change if human activity increases $[7,9,12]$. As mentioned in the Introduction, on the California coast, recent retreat rates have been lower than historical retreat rates in some regions and dynamic studies have also shown that regions with high levels of recent retreat had low historical retreat [5]. This is the opposite of what has happened on Mediterranean coasts, but the authors have pointed out that an inherent sampling bias could have occurred due to shorter observation intervals [1]. On the Gerra beach, the activity at the base of the cliff does not imply a retreat, and therefore it is considered to be inactive. This fact does not mean that all the coast is inactive, since very active Cantabrian coast portions have been observed $[6,7,12]$. As has been checked on the California coast, there is an alternation between regions of active and inactive coast, and more than $50 \%$ of the coast is inactive [5].

Spatial variations and changes between top, face, and base cliff retreat rates can be explained by common factors of sea cliff dynamics, such as geological structure, cliff collapses on top and base cliff, anthropogenic intervention [1-3], and storm succession, commonly affecting beaches on the Cantabrian coast [10-12,40]. Storms are an important factor, as it is well known that cliff erosion with subsequent deposition of large boulder debris is driven by large storms [52,53], although rainfall, groundwater pore pressure, and long-term vibrational disturbance from fair-weather waves also have an influence [25].

The turbiditic and claystone lithostratigraphic units are affected by wave energy during storm events overlapping with high tide, but ordinary events occur throughout the year and they rework and reshape sediments and beach landforms. During wave periods without a storm the coarse-grained beach and deposit of the storm berm protect the base of the cliff and there is no erosion.

Regarding the influence of storms on the evolution of the coastline, one must indicate that in the period 2000-2014 there were continuous storms [11,12]. There were four major storms in the winter of 2013 (from December 2013 to March 2014) [54]. However, during this period no significant differences in the evolution of the lower baseline of the cliff were detected. Measurements after the storms of March 2014 and subsequent years (2015-2019) showed an increase in landslides. The lower base line of the cliff remained stable, while the upper line of the cliff top was affected by landslides (Figure 6a). Therefore, there is a relationship between the influence of the waves on the lower part of the cliff that makes the cliff recede with an accumulation of terrestrial rainfall that causes the landslides. Therefore, landslides and rockfalls accumulate at the base of the cliff, while the boulder beach dissipates the energy and protects the base of the cliff. Between surveys there is no apparent change in the base line, while pushing the upper shoreline inland.

Geometric characterization has been carried out by different methods and data sources. On the one hand, series of aerial photographs have been used for evaluating coastal evolution over longer periods of time [12,55-58]. On the other hand, techniques based on obtaining massive data, such as LiDAR, UAV, and TLS, have demonstrated their effectiveness for studying changes in the coastal system [29,59-63]. High resolution orthophotos ( $4 \mathrm{~cm}$ pixel) have been obtained using UAV photogrammetric techniques, and from these a detailed analysis of the current limits of the top and base lines of the cliff has been possible. In addition, from UAV coverage, a point cloud was obtained of spatial resolution between 10 and $15 \mathrm{~cm}$ that defined the topography of both the beach and the cliff. TLS was used two times per year aimed at observing the topographic evolution of the beach and the cliff. This technique provided point clouds of spatial resolution $<10 \mathrm{~cm}$. This allowed us to evaluate, from the comparison of DEMs, the areas where landslides occurred on the cliff or the evolution of the level of sand on the beach.

To check the degree of precision of the different techniques used (aerial photogrammetry, LiDAR and UAV photogrammetry), a comparison of these techniques was made, with respect to the 
measurements with TLS (Figures 10-12). As previously stated, the maximum estimated error of the TLS measurements was $\pm 3 \mathrm{~cm}$. Profiles 1 and 9 (Figure 4a) were used for this analysis:

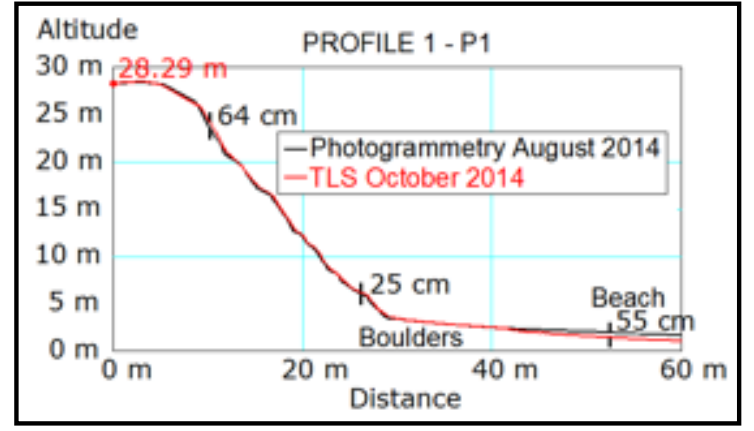

(a)

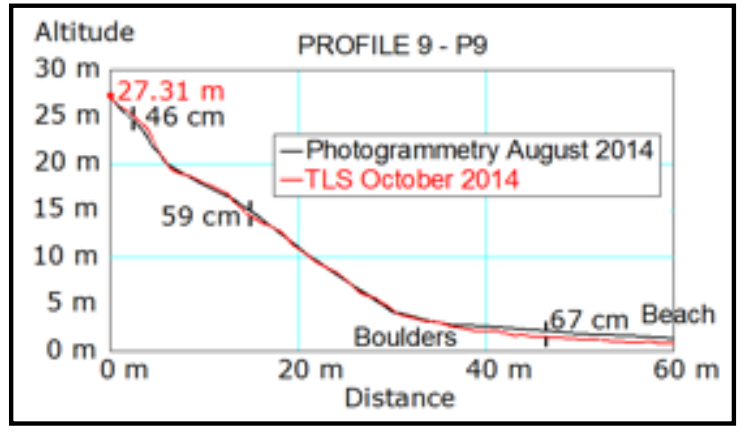

(b)

Figure 10. Comparison between the profiles obtained by photogrammetry and by TLS (2014). (a) Profile 1 (north area of the cliff); (b) Profile 9 (south area of the cliff).

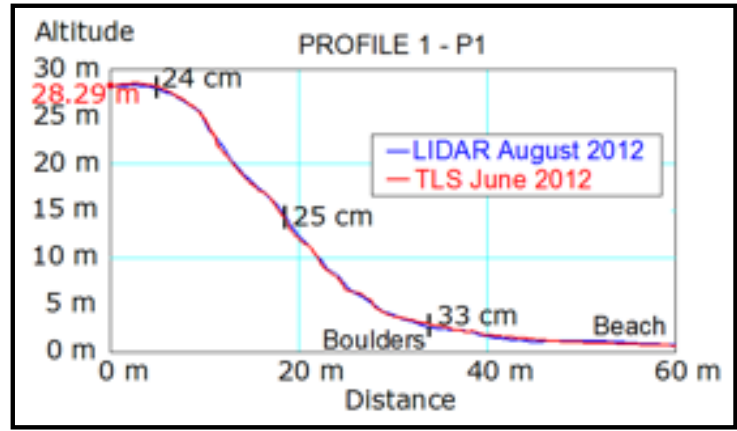

(a)

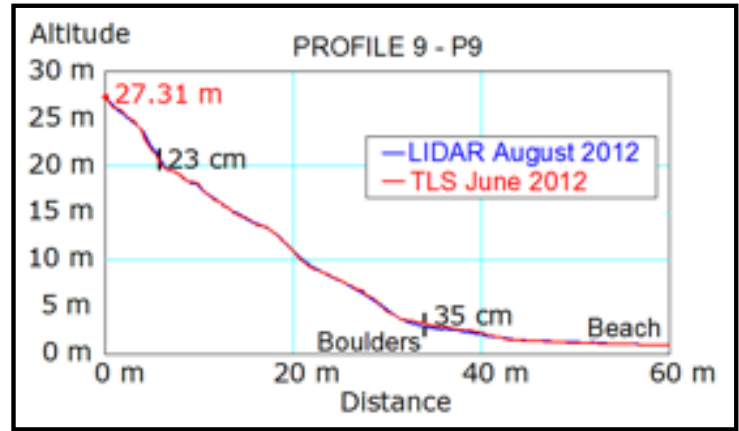

(b)

Figure 11. Comparison between the profiles obtained by LiDAR and by TLS (2012). (a) Profile 1 (north area of the cliff); (b) Profile 9 (south area of the cliff).

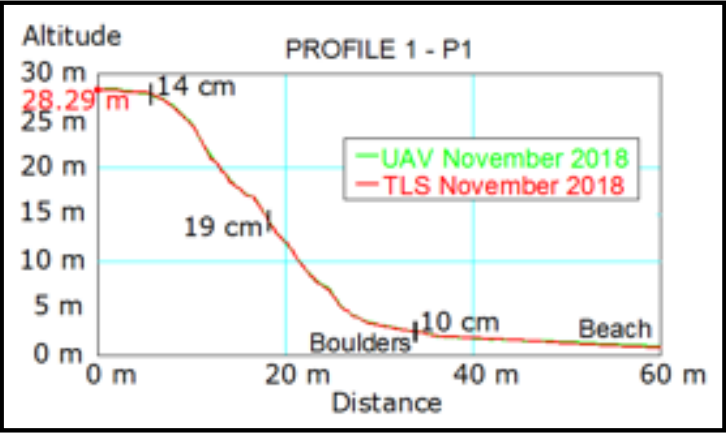

(a)

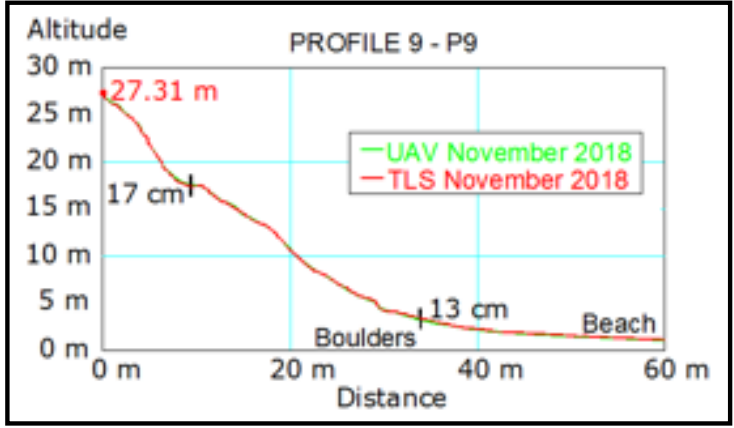

(b)

Figure 12. Comparison between the profiles obtained by UAV and by TLS (2018). (a) Profile 1 (north area of the cliff); (b) Profile 9 (south area of the cliff).

Comparison aerial photogrammetry and TLS There are many geomorphological investigations that compare the photogrammetric techniques supported by the structure from motion (SfM) technique with the TLS method [64-67], but this investigation makes a comparative analysis of the precision of the classical photogrammetric stereo restitution with TLS, as has been done by other authors [68-70]. This type of comparison is interesting due to the extensive mapping that was done using analytical or 
digital photogrammetry before the advent of automated SfM methods. In the case at hand, from the available photogrammetric flights, the one of August 2014 was chosen, since it approaches in time the TLS survey of October 2014. Therefore, the conditions of the Gerra beach in both DEMs are assumed to be similar (a difference of two months in the summer period without storms). In the case of the profiles shown in Figure 10, it can be seen that the maximum differences that the photogrammetry shows with respect to the TLS are $\pm 0.67 \mathrm{~m}$ in the zone of the beach. The maximum differences are distributed both in the area of the beach and on the cliff, and therefore not generalized in a specific area of them.

The photogrammetric mapping is not automatic, since it has been performed by a human being (operator with experience in photogrammetric restitution), where the altimetry interpretation is difficult to determine due to the lack of details and little slope in the beach area. There are significant differences in the areas with the steepest slope, where the errors are consistent with the equidistance between contour lines ( 2 meters) and the tolerance is $1 / 3$ of the equidistance, that is $\pm 0.67 \mathrm{~m}$. The photogrammetric flight of August 2017 was also compared with the TLS survey of November 2017, and they showed very similar results to those previously described (2014 flight and 2014 TLS).

LiDAR and TLS comparison The LiDAR flight of August 2012 was compared with the TLS survey of May 2012. It was previously indicated in the section on data collection and methodology with LiDAR that the maximum expected error for the LiDAR was $\pm 20 \mathrm{~cm}$. When comparing the DEM obtained from LiDAR and the DEM from the TLS survey, maximum errors of $\pm 35 \mathrm{~cm}$ are found in the area of the base line of the cliff where there are a large number of boulders (Figure 11). The difference in this area is foreseeable, since the LiDAR density is 0.5 points $/ \mathrm{m}^{2}$ and the TLS obtains hundreds or thousands of points $/ \mathrm{m}^{2}$, therefore, when the DEMs are generated large differences occur between them. In the area of the beach sand the differences are less than $\pm 20 \mathrm{~cm}$.

UAV and TLS comparison The UAV flight of November 2018 was compared with the TLS measurement of the same day. The maximum differences shown by the DEM from the UAV flight with respect to the DEM from the TLS is $\pm 19 \mathrm{~cm}$ in the cliff area, $\pm 13 \mathrm{~cm}$ in the pebble area, while in the beach area there are no major differences (Figure 12). The maximum values expected with the UAV flight were $\pm 4 \mathrm{~cm}$ (a very optimistic but not real value), since the topographic support determined by GPS positioning has an uncertainty of $\pm 3 \mathrm{~cm}$. Possibly, the differences obtained in the beach area, where they are $\pm 5 \mathrm{~cm}$, are more real.

UAV and TLS can generate errors around two very different types of terrain features, which must be taken into consideration:

1. The TLS can generate occlusions when the laser pulses hit a surface at an oblique angle from the scanner point of view (beach). The image processing algorithms used with the UAV photographs can generate occlusions on surfaces that have little inherent contrast or texture of color (beach area). This results in a dependency of the precision of each method on the landscape in question [71].

2. The TLS and UAV methods are capable of collecting data at very different spatial scales. This has a substantial influence on the application of these methods and needs to be considered when making a comparison between them. In this case, the scale of both methods is very similar, since the measurement errors are $\pm 4 \mathrm{~cm}$.

Interpreting the maps obtained from the photogrammetric flights in Figure 5, it is stressed that there is always a retreat in the top line, while the base of the cliff does not go backwards. Between 1956 and 2001 (45 years) the setback occurred mainly in the area of the beach access road, possibly caused by its construction, since in 1956 it was a very narrow dirt road and now it is a larger asphalt road, which has generated landslides due to the existence of greater slopes. During this period, there has also been a great setback in the south of the beach (near point A) (Figure 6a), and it is in this area where there has been a set of various landslides. The areas of the coastline that had the least setback between 1956 and 2001 are those that have been affected the most in the period 2001-2017 (16 years), with the average values of 20 meters of retreat during this period (Figure 6b). In total, during the period 1956-2017, the maximum retreat of the coastline at the top of the cliff was 42 meters, and the average value for the entire cliff was $25 \mathrm{~m}$. 
Regarding the results obtained with TLS during the period 2012-2020, there were no major changes between the winter and summer periods. Therefore, the measurement made after the summer period (October-November) would not be necessary, and one annual measurement would be sufficient. However, two measurements per year allowed us to know in more detail the evolution of the beach level and of the base and top lines of the cliff. It also allowed us to make a volumetric control for the winter and summer periods (Figure 9) and to undertake detailed studies of the annual dynamics of the beach. The profiles generated from the TLS DEMs show no changes in the cliff baseline toe, excep after extreme storms that push this lower line landward with minor landslides (fall of 2013 and spring of 2014). Instead, the same DEMs show changes in the top line of the cliff, showing large landslides (for example, between the fall of 2017 and the spring of 2018) (Figure 9). The storms that occurred during the winter of 2013 have been the most aggressive on the Cantabrian coast so far in the 21st century, but the footprint left on Gerra beach has been much lower than that of other beaches in the Cantabrian Sea (Spain).

\section{Conclusions}

The application of different geomatic techniques (aerial photogrammetry, LiDAR, UAV photogrammetry, and TLS) to acquire data on the beach and cliff of Gerra has allowed us to obtain two main pieces of information. On the one hand, the precisions of the different techniques for this purpose, and on the other hand, the receding rhythms of the cliff coast. This information can be applied to other sections of the Cantabrian coast for empiric and numerical models of cliff retreat, considering factors such as waves, currents, beach and cliff location, onshore morphology (sand beach, pebble beach, shore platform), intensity and frequency of storms, wind directions, rainfall, geological structure, sedimentary deposits, lithology, geomorphic inheritance and present day processes (karstic, tectonic), and human use on the Cantabrian or Atlantic coast, both located in a temperate oceanic climate.

The combination of techniques and their adaptation to the geomorphological particularity and the orographic situation of the beach, serve as a reference for its application in the control of the dynamics of beaches and the retreat of cliffs. We can conclude that there is no single ideal geomatic technique for each situation, and different techniques must be complemented to solve the problem posed. In the case of the Gerra beach cliff, as long as there are no areas of occlusions caused by the orography of the cliff or vegetation, the most accurate remote sensor technique is the TLS followed by the UAV photogrammetry. However, if these occlusions occur, both techniques are complementary, and therefore occlusions measured from the beach with TLS can be avoided by adding 3D points obtained from the UAV flight. Aerial LiDAR is the third technique for precision, although its density was too low for this objective. Lastly, photogrammetric flights provide less precision, but they are the most useful source to obtain data on past evolution and over a longer term. Therefore, to obtain data for modeling future evolution of the coast, faced with theoretical assumptions such as increased number and strength of storms, sea level rise, changes in rainfall or human pressure on the coast, old photogrammetric flights are the best resource. This classification shows a direct link between the precision of the technique and the cartographic scale obtainable from the collected data, that is, the better the precision of the technique, the larger the scale.

The use of different geomatic techniques has provided relevant and decisive data on the retreat rhythms and the evolution of the beach and the cliff of Gerra for the period 1956-2020. The different rates of coastal retreat for the last 64 years have been evaluated with great precision. A small acceleration of the retreat in the 21st century has been observed in relation to the 20th century. Throughout the period, high retreat rates have been found, as befits the European Atlantic cliff coasts. However, these variations of the Gerra beach coastline are insignificant with respect to the setbacks of other beaches located on the Cantabrian coast.

Large storms have been responsible for erosion on the lower cliff base line, where they have caused small landslides and rockfall. This erosion affects the setback of the cliff top line. Differential retreat rhythms have been found between the base line and the top line of the cliff, with retreat rhythms in the 
upper portion that double the rhythms of the lower one. This fact leads to a degradation of the cliff and a more irregular coastline, which together with the increase in the retreat rates implies greater instability that can affect human infrastructure and buildings. There are no infrastructures on the Gerra beach, but they are being affected on the nearby beach of San Vicente-Merón and other Cantabrian beaches. Coastal authorities and territorial managers must implement control plans based on accurate data on coastal dynamics, and geomatic techniques have been proven to be suitable to monitor the dynamic of cliffs.

Author Contributions: Conceptualization, J.J.d.S.B. and E.S.-C.; Methodology, J.J.d.S.B., E.S.-C., M.S.-F. and M.G.-L.; Software, J.J.d.S.B., M.S.-F. and P.R.; Validation, J.J.d.S.B., E.S.-C. and P.R.; Formal Analysis, J.J.d.S.B., E.S.-C., M.S.-F. and MGL; Investigation, J.J.d.S.B., E.S.-C., M.S.-F., M.G.-L. and P.R.; Resources, J.J.d.S.B. and E.S.-C.; Data Curation, J.J.d.S.B., E.S.-C., M.S.-F., M.G.-L. and P.R.; Writing-Original Draft Preparation, J.J.d.S.B., E.S.-C., M.S.-F., M.G.-L. and P.R.; Writing-Review \& Editing, J.J.d.S.B., E.S.-C., M.S.-F., M.G.-L. and P.R. All authors have read and agreed to the published version of the manuscript.

Funding: This research was funded by Junta de Extremadura and European Regional Development Fund (ERDF) grant number GR18053 to the Research Group NEXUS (University of Extremadura) and also by FCT-project UIDB/50019/2020-Instituto Dom Luiz.

Conflicts of Interest: The authors declare no conflict of interest.

\section{References}

1. Mushkin, A.; Katz, O.; Porat, N. Overestimation of short-term coastal cliff retreat rates in the eastern Mediterranean resolved with a sediment budget approach. Earth Surf. Process. Landf. 2019, 44, 179-190. [CrossRef]

2. Sunamura, T. Rocky coast processes: With special reference to the recession of soft rock cliffs. Proc. Japan Acad. Ser. B Phys. Biol. Sci. 2015, 91, 481-500. [CrossRef] [PubMed]

3. Costa, S.; Maquaire, O.; Letortu, P.; Thirard, G.; Compain, V.; Roulland, T.; Medjkane, M.; Davidson, R.; Graff, K.; Lissak, C. Sedimentary Coastal cliffs of Normandy: Modalities and quantification of retreat. J. Coast. Res. 2019, 88, 46-60. [CrossRef]

4. Young, A.P.; Carilli, J.E. Global distribution of coastal cliffs. Earth Surf. Process. Landf. 2019, 44, $1309-1316$. [CrossRef]

5. Young, A.P. Decadal-scale coastal cliff retreat in southern and central California. Geomorphology 2018, 300, 164-175. [CrossRef]

6. Losada, M.A.; Medina, R.; Vidal, C.; Roldan, A. Historical evolution and morphological analysis of "El Puntal” spit, Santander (Spain). J. Coast. Res. 1991, 7, 711-722.

7. Garrote, J.; Garzón, G.; Page, J. Condicionamientos antrópicos en la erosión de la playa de Oyambre (Cantabria). In Proceedings of the Actas V Reunión de Cuaternario Ibérico, Lisbon, Coambra, Portugal, July 2001; Volume 1, pp. 67-70.

8. Lorenzo, F.; Alonso, A.; Pagés, J.L. Erosion and accretion of beach and spit systems in Northwest Spain: A response to human activity. J. Coast. Res. 2007, 2007, 834-845. [CrossRef]

9. Flor-Blanco, G.; Pando, L.; Morales, J.A.; Flor, G. Evolution of beach-dune fields systems following the construction of jetties in estuarine mouths (Cantabrian coast, NW Spain). Environ. Earth Sci. 2015, 73, 1317-1330. [CrossRef]

10. Garrote, J.; Heydt, G.; Alcantara-Carrio, J. Influencia de Los temporales sobre el transporte de sedimentos en la Playa de Oyambre (Cantabria, N de España). In Proceedings of the Actas V Reunión Nacional de Geomorfología, Valladolid, Spain, 26 June 2002; pp. 361-371.

11. Sanjosé, J.D.; Serrano, E.; Berenguer, F.; González-Trueba, J.J.; Gómez-Lende, M.; González-García, M.; Guerrero-Castro, M. Evolución histórica y actual de la línea de costa en la playa de Somo (Cantabria), mediante el empleo de la fotogrametría aérea y escáner láser terrestre. Cuaternario Geomorfol. 2016, 30, 119-130. [CrossRef]

12. De Sanjosé Blasco, J.J.; Gómez-Lende, M.; Sánchez-Fernández, M.; Serrano-Cañadas, E. Monitoring retreat of coastal sandy systems using geomatics techniques: Somo Beach (Cantabrian Coast, Spain, 1875-2017). Remote Sens. 2018, 10, 25. [CrossRef] 
13. Arteaga, C.; Juan de Sanjose, J.; Serrano, E. Terrestrial photogrammetric techniques applied to the control of a parabolic dune in the Liencres dune system, Cantabria (Spain). Earth Surf. Process. Landf. 2008, 33, 2201-2210. [CrossRef]

14. Letortu, P.; Costa, S.; Maquaire, O.; Delacourt, C.; Augereau, E.; Davidson, R.; Suanez, S.; Nabucet, J. Retreat rates, modalities and agents responsible for erosion along the coastal chalk cliffs of Upper Normandy: The contribution of terrestrial laser scanning. Geomorphology 2015, 245, 3-14. [CrossRef]

15. Letortu, P.; Costa, S.; Bensaid, A.; Cador, J.-M.; Quénol, H. Vitesses et modalités de recul des falaises crayeuses de Haute-Normandie (France): Méthodologie et variabilité du recul. Géomorphologie Reli. Process. Environ. 2014, 20, 133-144. [CrossRef]

16. Letortu, P.; Costa, S.; Cador, J.; Coinaud, C.; Cantat, O. Statistical and empirical analyses of the triggers of coastal chalk cliff failure. Earth Surf. Process. Landf. 2015, 40, 1371-1386. [CrossRef]

17. Kuhn, D.; Prüfer, S. Coastal cliff monitoring and analysis of mass wasting processes with the application of terrestrial laser scanning: A case study of Rügen, Germany. Geomorphology 2014, 213, 153-165. [CrossRef]

18. Young, A.P.; Ashford, S.A. Instability investigation of cantilevered seacliffs. Earth Surf. Process. Landf. J. Br. Geomorphol. Res. Group 2008, 33, 1661-1677. [CrossRef]

19. Toimil, A.; Losada, I.J.; Camus, P.; Díaz-Simal, P. Managing coastal erosion under climate change at the regional scale. Coast. Eng. 2017, 128, 106-122. [CrossRef]

20. Masselink, G.; Russell, P.; Rennie, A.; Brooks, S.; Spencer, T. Impacts of climate change on coastal geomorphology and coastal erosion relevant to the coastal and marine environment around the UK. MCCIP Sci. Rev. 2020, 2020, 158-189.

21. Martínez, C.; Contreras-López, M.; Winckler, P.; Hidalgo, H.; Godoy, E.; Agredano, R. Coastal erosion in central Chile: A new hazard? Ocean Coast. Manag. 2018, 156, 141-155. [CrossRef]

22. Bruno, M.; Molfetta, M.; Pratola, L.; Mossa, M.; Nutricato, R.; Morea, A.; Nitti, D.; Chiaradia, M. A Combined Approach of Field Data and Earth Observation for Coastal Risk Assessment. Sensors 2019, 19, 1399. [CrossRef]

23. Valentini, N.; Saponieri, A.; Danisi, A.; Pratola, L.; Damiani, L. Exploiting remote imagery in an embayed sandy beach for the validation of a runup model framework. Estuar. Coast. Shelf Sci. 2019, 225, 106244. [CrossRef]

24. Terefenko, P.; Paprotny, D.; Giza, A.; Morales-Nápoles, O.; Kubicki, A.; Walczakiewicz, S. Monitoring cliff erosion with LiDAR surveys and bayesian network-based data analysis. Remote Sens. 2019, 11, 843. [CrossRef]

25. Young, A.P.; Guza, R.T.; O’Reilly, W.C.; Burvingt, O.; Flick, R.E. Observations of coastal cliff base waves, sand levels, and cliff top shaking. Earth Surf. Process. Landf. 2016, 41, 1564-1573. [CrossRef]

26. Katz, O.; Mushkin, A. Characteristics of sea-cliff erosion induced by a strong winter storm in the eastern Mediterranean. Quat. Res. 2013, 80, 20-32. [CrossRef]

27. Dornbusch, U.; Robinson, D.A.; Moses, C.A.; Williams, R.B.G. Temporal and spatial variations of chalk cliff retreat in East Sussex, 1873 to 2001. Mar. Geol. 2008, 249, 271-282. [CrossRef]

28. Benumof, B.T.; Griggs, G.B. The dependence of seacliff erosion rates on cliff material properties and physical processes: San Diego County, California. Shore Beach 1999, 67, 29-41.

29. Rosser, N.J.; Petley, D.N.; Lim, M.; Dunning, S.A.; Allison, R.J. Terrestrial laser scanning for monitoring the process of hard rock coastal cliff erosion. Q. J. Eng. Geol. Hydrogeol. 2005, 38, 363-375. [CrossRef]

30. Young, A.P.; Ashford, S.A. Application of airborne LIDAR for seacliff volumetric change and beach-sediment budget contributions. J. Coast. Res. 2006, 22, 307-318. [CrossRef]

31. Marques, F. Rates, patterns, timing and magnitude-frequency of cliff retreat phenomena. A case study on the west coast of Portugal. Zeitschrift für Geomorphol. New Folge Suppl. Vol. 2006, 144, 231-257.

32. Pierre, G.; Lahousse, P. The role of groundwater in cliff instability: An example at Cape Blanc-Nez (Pas-de-Calais, France). Earth Surf. Process. Landf. J. Br. Geomorphol. Res. Group 2006, 31, 31-45. [CrossRef]

33. Olsen, M.J.; Johnstone, E.; Driscoll, N.; Ashford, S.A.; Kuester, F. Terrestrial laser scanning of extended cliff sections in dynamic environments: Parameter analysis. J. Surv. Eng. 2009, 135, 161-169. [CrossRef]

34. Hernández-Pacheco, F; Amor, I.A. Fisiografía y sedimentología de la playa y ría de San Vicente de la Barquera (Santander). Estud. Geológicos 1966, 22, 1-23.

35. Mary, G. Évolution de la Bordure Côtière Asturienne (Espagne) du Néogène á l'Actuel. Ph.D. Thesis, Université de Caen, Caen, France, 1979.

36. Mary, G. Evolución del margen costero de la Cordillera Cantábrica en Asturias desde el Mioceno. Trab. Geol. $1983,13,3-37$. 
37. González-Amuchástegui, M.J.; Serrano, E.; Edeso, J.M.; Meaza, G. Cambios del nivel del mar durante el Cuaternario y morfología litoral en la costa oriental cantábrica. (País Vasco y Cantabria). In Proceedings of the Geomorfologia Litoral i Quaternari; Sanjaume, E., Mateu, J., Eds.; Universitat de Valencia: Valencia, Spain, 2005; pp. 167-180.

38. Flor, G.; Flor-Blanco, G. Raised beaches in the Cantabrian coast. In Landscapes and Landforms of Spain; Springer: Berlin/Heidelberg, Germany, 2014; pp. 239-248.

39. Monino, M.; Diaz de Teran, J.R.; Cendrero, A. Variaciones del nivel del mar en la costa de Cantabria durante el Cuaternario. In Proceedings of the Reunión sobre el Cuaternario 7, Santander, Spain, 21-26 September 1987; pp. 233-236.

40. Garzón, G.; Alonso, A.; Torres, T.; Llamas, J. Edad de las playas colgadas y de las turberas de Oyambre y Merón (Cantabria). Geogaceta 1996, 20, 498-501.

41. IGME. Mapa Geológico de España E. 1/50.000. Comillas, $N^{o}$ 33.; Ministerio de Industria (España): Madrid, Spain, 2009.

42. IGME. Mapa Geológico de España E. 1/50.000. Comillas, $N^{0}$ 33; Ministerio de Industria (España): Madrid, Spain, 1990.

43. Gómez-Pazo, A.; Pérez-Alberti, A. Vulnerability of the Galician coast to marine storms in the context of global change. Sémata Cienc. Sociais Humanid. 2017, 29, 117-142.

44. Pérez, J.A.; Bascon, F.M.; Charro, M.C. Photogrammetric usage of 1956-57 usaf aerial photography of Spain. Photogramm. Rec. 2014, 29, 108-124. [CrossRef]

45. Soteres, C.; Rodríguez, A.F.; Martínez, J.; Ojeda, J.C.; Romero, E.; Abad, P.; Sánchez, A.; González, C.; Juanatey, M.; Ruiz, C.; et al. Publicación de datos LiDAR mediante servicios web estándar. In Proceedings of the II Jornadas Ibéricas de Infraestructuras de Datos Espaciales, Barcelona, Spain, 9-10 November 2011; Volume 2, p. 16.

46. Sanjosé, J.J.; Martínez, E.; López, M.; Atkinson, A.D.J. Topografía Para Estudios de Grado; Universidad de Extremadura. Servicio de Publicaciones: Bellisco, Spain, 2013.

47. Hoffmeister, D.; Tilly, N.; Curdt, C.; Aasen, H.; Ntageretzis, K.; Hadler, H.; Willershäuser, T.; Vött, A.; Bareth, G. Terrestrial laser scanning for coastal geomorphologic research in western Greece. Int. Arch. Photogramm. Remote Sens. Spat. Inf. Sci. 2012, 39, 511-516. [CrossRef]

48. Lindenbergh, R.C.; Soudarissanane, S.S.; De Vries, S.; Gorte, B.G.H.; De Schipper, M.A. Aeolian beach sand transport monitored by terrestrial laser scanning. Photogramm. Rec. 2011, 26, 384-399. [CrossRef]

49. González Amuchastegui, M.J.; Ibisate González de Matauco, A.; Rico Lozano, I.; Sánchez Fernández, M.; Sanjosé, J.J. Cambios geomorfológicos y evolución de una barra de arena en la desembocadura del río Lea, Lekeitio-Mendexa (Bizkaia). Cuaternario Geomorfol. 2016, 30, 75-85. [CrossRef]

50. Bremer, M.; Sass, O. Combining airborne and terrestrial laser scanning for quantifying erosion and deposition by a debris flow event. Geomorphology 2012, 138, 49-60. [CrossRef]

51. Jaboyedoff, M.; Oppikofer, T.; Abellán, A.; Derron, M.-H.; Loye, A.; Metzger, R.; Pedrazzini, A. Use of LIDAR in landslide investigations: A review. Nat. Hazards 2012, 61, 5-28. [CrossRef]

52. Hansom, J.D. Coastal sensitivity to environmental change: A view from the beach. Catena 2001, 42, $291-305$. [CrossRef]

53. Hall, A.M.; Hansom, J.D.; Jarvis, J. Patterns and rates of erosion produced by high energy wave processes on hard rock headlands: The Grind of the Navir, Shetland, Scotland. Mar. Geol. 2008, 248, 28-46. [CrossRef]

54. Flor, G.; Flor-Blanco, G.; Flores-Soriano, C.; Alcántara-Carrió, J.; Montoya-Mpontes, I. Efectos de los temporales de invierno de 2014 sobre la costa asturiana. VIII Jorn. Geomorfol. Litoral Geo-Temas 2015, 15, $17-20$.

55. Catalão, J.; Catita, C.; Miranda, J.; Dias, J. Photogrammetric analysis of the coastal erosion in the Algarve (Portugal). Géomorphologie Reli. Process. Environ. 2002, 8, 119-126. [CrossRef]

56. Esposito, G.; Salvini, R.; Matano, F.; Sacchi, M.; Troise, C. Evaluation of geomorphic changes and retreat rates of a coastal pyroclastic cliff in the Campi Flegrei volcanic district, southern Italy. J. Coast. Conserv. 2018, 22, 957-972. [CrossRef]

57. Marques, F. Regional scale sea cliff hazard assessment at sintra and cascais counties, western coast of Portugal. Geoscience 2018, 8, 80. [CrossRef]

58. Gómez-Pazo, A.; Pérez-Alberti, A.; Pérez, X.L.O. Recent evolution (1956-2017) of rodas beach on the Cíes Islands, Galicia, NW Spain. J. Mar. Sci. Eng. 2019, 7, 125. [CrossRef] 
59. Earlie, C.S.; Masselink, G.; Russell, P.E.; Shail, R.K. Application of airborne LiDAR to investigate rates of recession in rocky coast environments. J. Coast. Conserv. 2015, 19, 831-845. [CrossRef]

60. Gonçalves, J.A.; Henriques, R. UAV photogrammetry for topographic monitoring of coastal areas. ISPRS J. Photogramm. Remote Sens. 2015, 104, 101-111. [CrossRef]

61. Long, N.; Millescamps, B.; Guillot, B.; Pouget, F.; Bertin, X. Monitoring the topography of a dynamic tidal inlet using UAV imagery. Remote Sens. 2016, 8, 387. [CrossRef]

62. Mancini, F.; Castagnetti, C.; Rossi, P.; Dubbini, M.; Fazio, N.L.; Perrotti, M.; Lollino, P. An integrated procedure to assess the stability of coastal rocky cliffs: From UAV close-range photogrammetry to geomechanical finite element modeling. Remote Sens. 2017, 9, 1235. [CrossRef]

63. Westoby, M.J.; Lim, M.; Hogg, M.; Pound, M.J.; Dunlop, L.; Woodward, J. Cost-effective erosion monitoring of coastal cliffs. Coast. Eng. 2018, 138, 152-164. [CrossRef]

64. Gómez-Gutiérrez, Á.; De Sanjosé-Blasco, J.J.; Lozano-Parra, J.; Berenguer-Sempere, F.; De Matías-Bejarano, J. Does HDR pre-processing improve the accuracy of 3D models obtained by means of two conventional SfM-MVS software packages? The case of the corral del veleta rock glacier. Remote Sens. 2015, 7, 10269-10294. [CrossRef]

65. Crawford, A.J.; Mueller, D.; Joyal, G. Surveying drifting icebergs and ice islands: Deterioration detection and mass estimation with aerial photogrammetry and laser scanning. Remote Sens. 2018, 10, 575. [CrossRef]

66. Jaud, M.; Kervot, M.; Delacourt, C.; Bertin, S. Potential of smartphone SfM photogrammetry to measure coastal morphodynamics. Remote Sens. 2019, 11, 2242. [CrossRef]

67. Hayakawa, Y.S.; Obanawa, H. Volumetric change detection in bedrock coastal cliffs using terrestrial laser scanning and uas-based SFM. Sensors 2020, 20, 3403. [CrossRef]

68. Lichti, D.D.; Gordon, S.; Stewart, M.; Franke, J.; Tsakiri, M. Comparison of digital photogrammetry and laser scanning. In Proceedings of the CIPA W6 International Workshop, Corfu, Greece, 1-2 September 2002; pp. 39-47.

69. Martin, C.D.; Tannant, D.D.; Lan, H. Comparison of terrestrial-based, high resolution, LiDAR and digital photogrammetry surveys of a rock slope. In Proceedings of the Proceedings 1st Canada-US Rock Mechanics Symp, British, DC, Canada, 27-31 May 2007; pp. 37-44.

70. Sturzenegger, M.; Stead, D. Close-range terrestrial digital photogrammetry and terrestrial laser scanning for discontinuity characterization on rock cuts. Eng. Geol. 2009, 106, 163-182. [CrossRef]

71. Seymour, A.C.; Ridge, J.T.; Rodriguez, A.B.; Newton, E.; Dale, J.; Johnston, D.W. Deploying Fixed Wing Unoccupied Aerial Systems (UAS) for Coastal Morphology Assessment and Management. J. Coast. Res. 2018, 34, 704-717. [CrossRef]

Publisher's Note: MDPI stays neutral with regard to jurisdictional claims in published maps and institutional affiliations.

(C) 2020 by the authors. Licensee MDPI, Basel, Switzerland. This article is an open access article distributed under the terms and conditions of the Creative Commons Attribution (CC BY) license (http://creativecommons.org/licenses/by/4.0/). 